\title{
Temporal dynamics of gene expression in the lung in a baboon model of $E$. coli sepsis
}

\author{
Hua Zhu ${ }^{1}$, Yuhong Tang ${ }^{2}$, Lacramioara Ivanciu1 ${ }^{1}$, Michael Centola ${ }^{2}$, \\ Cristina Lupu ${ }^{1}$, Fletcher B Taylor Jr¹,3 and Florea Lupu*1,3
}

\author{
Address: ${ }^{1}$ Cardiovascular Biology Research Program, Oklahoma Medical Research Foundation, Oklahoma City, OK, USA, ${ }^{2}$ Arthritis and \\ Immunology Program, Oklahoma Medical Research Foundation, Oklahoma City, OK, USA and ${ }^{3}$ Department of Pathology, Oklahoma University \\ Health Sciences Center, Oklahoma City, OK, USA \\ Email: Hua Zhu - hua-zhu@omrf.ouhsc.edu; Yuhong Tang - yuhong-tang@omrf.ouhsc.edu; Lacramioara Ivanciu - ivanciul@omrf.ouhsc.edu; \\ Michael Centola - michael-centola@omrf.ouhsc.edu; Cristina Lupu - cristina-lupu@omrf.ouhsc.edu; Fletcher B Taylor - fletcher- \\ taylor@omrf.ouhsc.edu; Florea Lupu* - florea-lupu@omrf.ouhsc.edu \\ * Corresponding author
}

Published: 26 February 2007

BMC Genomics 2007, 8:58 doi:10.1/86/147/-2/64-8-58
Received: 5 October 2006

Accepted: 26 February 2007

This article is available from: http://www.biomedcentral.com/l47I-2/64/8/58

(c) 2007 Zhu et al; licensee BioMed Central Ltd.

This is an Open Access article distributed under the terms of the Creative Commons Attribution License (http://creativecommons.org/licenses/by/2.0), which permits unrestricted use, distribution, and reproduction in any medium, provided the original work is properly cited.

\begin{abstract}
Background: Bacterial invasion during sepsis induces disregulated systemic responses that could lead to fatal lung failure. The purpose of this study was to relate the temporal dynamics of gene expression to the pathophysiological changes in the lung during the first and second stages of $E$. coli sepsis in baboons.

Results: Using human oligonucleotide microarrays, we have explored the temporal changes of gene expression in the lung of baboons challenged with sublethal doses of $E$. coli. Temporal expression pattern and biological significance of the differentially expressed genes were explored using clustering and pathway analysis software. Expression of selected genes was validated by realtime PCR. Cytokine levels in tissue and plasma were assayed by multiplex ELISA. Changes in lung ultrastructure were visualized by electron microscopy. We found that genes involved in primary inflammation, innate immune response, and apoptosis peaked at $2 \mathrm{hrs}$. Inflammatory and immune response genes that function in the stimulation of monocytes, natural killer and T-cells, and in the modulation of cell adhesion peaked at $8 \mathrm{hrs}$, while genes involved in wound healing and functional recovery were upregulated at $24 \mathrm{hrs}$.
\end{abstract}

Conclusion: The analysis of gene expression modulation in response to sepsis provides the baseline information that is crucial for the understanding of the pathophysiology of systemic inflammation and may facilitate the development of future approaches for sepsis therapy.

\section{Background}

Sepsis and its complications represent a complex disease encompassing multiple pathological processes, including uncontrolled systemic inflammation, coagulopathy, microvascular and hemodynamic abnormalities. The development of septic shock, acute respiratory distress syndrome (ARDS) and the onset of multiple organ (lung, liver, kidney, heart) dysfunction (MOD) are landmarks of severe sepsis, one of the leading causes of mortality in critically ill patients[1]. Despite significant progress, the pathophysiology of sepsis and its sequels are still not fully understood. One early MOD symptom associated with 
sepsis is acute lung injury[2]. Lipopolysaccharide (LPS) was considered the main component in the induction of lung injury in gram-negative bacterial sepsis. LPS recognition by host's Toll-Like Receptors (TLRs) is followed by subsequent activation of a plethora of signal transduction cascades in different lung cells[3], leading to the generation of a multitude of inflammatory mediators, including proinflammatory cytokines, chemokines, adhesion molecules, reactive oxygen species and nitric oxide[4,5]. This process is accompanied by massive influx of neutrophils and macrophages into the lung, and by severe damage to the lung endothelium and alveolar epithelium $[6,7]$. Other mediators including microbial signal molecules, complement activation products, and coagulation factors play a critical role in the pathophysiology of sepsis $[8,9]$. However, neither the full spectrum of mediators acting in multiple pathways nor the temporal expression pattern of each individual mediator, alone or in combination, are clear to date. Understanding the pathogenesis of sepsis has been particularly challenging as this involves multiple functional pathways, comprising hundreds of genes. We reasoned that microarray technology would likely provide novel insights into the pathogenesis of sepsis or acute lung injury by allowing genomic-scale analysis of the gene transcription in specific organs. In the past, this technology has been used to study the pattern of gene expression either on cells exposed in vitro to LPS [10-13] or E. coli[14], or on blood cells isolated from septic patients[15]. So far, global gene expression studies in animal models of sepsis have been limited and restricted to rodents $[2,6,16]$. However, mouse models do not reflect the pathophysiology of the disease in humans (e.g., mice do not produce IL-8, which is a major proinflammatory chemokine in humans). Our laboratory had characterized a baboon model of compensated (non-lethal) E. coli sepsis, which is comparable in nearly all physiological and immunological aspects to human disease. Similar to humans, the baboon model of compensated response to inflammatory stress exhibits two stages, each with its unique inflammatory and haemostatic response signature[17]. Baboon-specific microarrays are not available, yet, but given the close evolutionary relationship between baboons and humans, human microarrays have been successfully used to study gene expression patterns in nonhuman primates [18-21] and several cross-hybridization studies between these species have been attempted [2224]. Using the baboon model of sepsis, here, we report for the first time a global analysis of gene expression patterns in the lung of baboons during the first $24 \mathrm{hrs}$ post $E$. coli challenge. The purpose of this study was to relate the temporal dynamics of gene expression in the lung to what we already have learned in previous studies about the compensated response of the baboon to sublethal E. coli challenge. Our results provide information relating to the temporal changes of the gene expression during inflam- mation in response to $E$. coli infusion, which could serve as a basis for discovery of new diagnostic and prognostic indicators and biomarkers, as well as the identification and validation of new molecular targets for drug development.

\section{Results \\ I. Global analysis of gene expression profile in baboon septic lung}

Oligonucleotide microarrays were used to study the timecourse of gene expression in the lung of baboons challenged with $E$. coli. Approximately one third of the genes on the chip $(7240$ out of 21,423$)$ were detectable above the background.

Genes up- or down-regulated more than 2 times over controls at any time-point (Figures $1 \mathrm{a}$ and $1 \mathrm{~b}$ ) were considered differentially expressed. At $2 \mathrm{hrs}$ after E. coli challenge, expression of 83 genes was modulated by treatment (70 up- and 13 down-regulated); at 8 hrs, 193 (110 genes up- and 83 down-regulated); and at $24 \mathrm{hrs}, 256$ (113 up- and 142 down-regulated). Four genes (S100A8, S100A9, WARS, GBP2 and CCL3L1) were up-regulated and two genes (THBD and SPARCL1) were down-regulated at all three time points. The genes up-regulated during the time-course of the experiment are listed in Table 1, and the down-regulated genes are listed in Table 2. Most of down-regulated genes (95\%) were detected in the lung at $8 \mathrm{hrs}$ and $24 \mathrm{hrs}$. These genes are involved in inflammation and immune response, protein scaffolding and blood coagulation, collagen and extracellular matrix catabolism, cell adhesion and migration, cell cycle, stress response, protein transport and synthesis, energy generation and transcriptional regulation (Table 2).

\section{Validation of microarray results by real time $R T-P C R$}

To confirm the microarray results, the expression level of nine genes was measured by real-time quantitative RTPCR using the same mRNA samples used for microarray analysis. The primer sequences of these genes are listed in Table 3. Microarray and real-time PCR data were highly concordant (Table 4).

\section{Functional analysis of gene expression in lung during $\mathbf{E}$. coli sepsis \\ Inflammatory/immune response genes \\ a. Induced proinflammatory proteins}

At 2 hrs, 25 of the 70 up-regulated genes belong to the inflammatory/immune pathway (Table 2; Figure 1a). Five of the most highly up-regulated genes were chemokines (CXCL2, CCL20) or inflammation-associated genes (S100A8, S100A9, GBP2). Other genes up-regulated at 2 hrs include CXCL2, CCL20, IL1B, CXCL10, CCL2, IL6, IL15RA. Genes upregulated only at 8 hrs include CXCL11, 


\section{Upregulated genes}

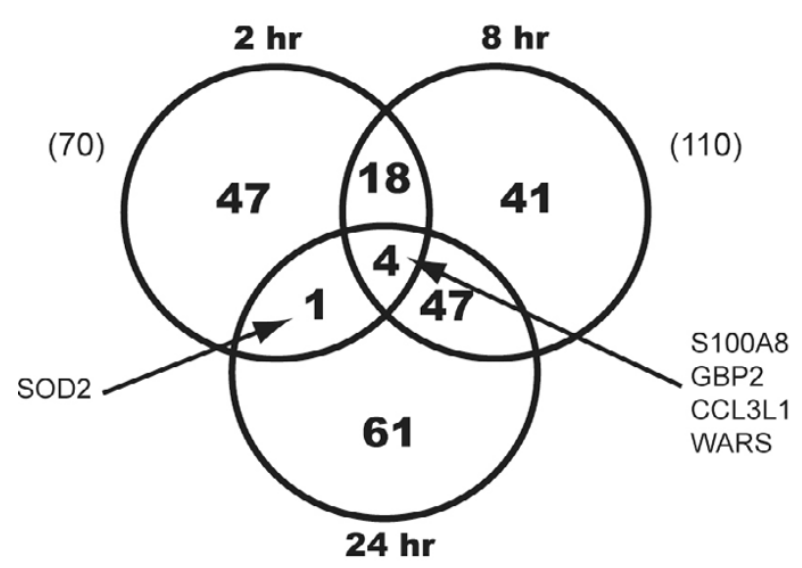

(113)

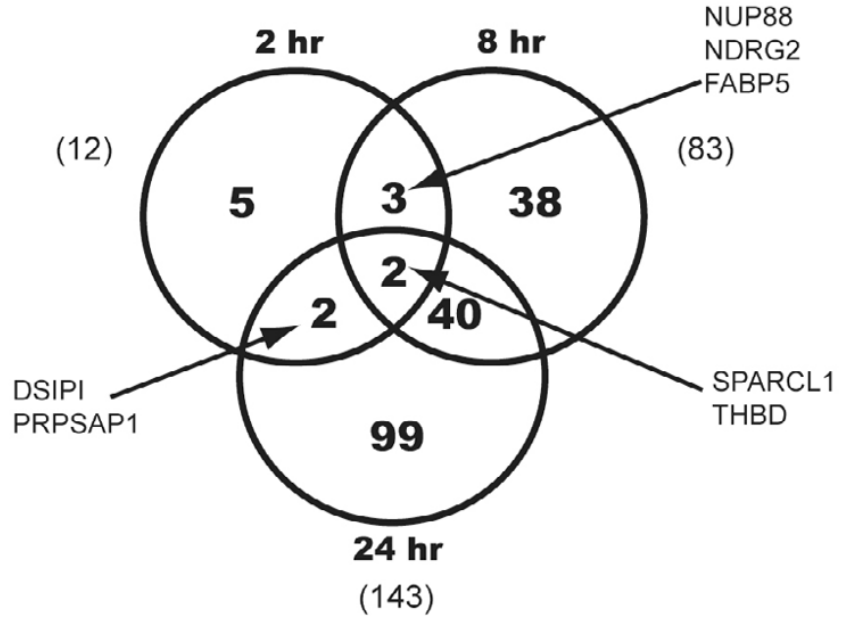

b

\section{Downregulated genes}

(143)

\section{a}

\section{Figure I}

Venn diagram of the differentially expressed genes in the $E$. coli challenged septic baboons. a: genes up-regulated; b: genes down-regulated at three time points.

IRF1, VCAM1, CLECSF5, GBP1, S100A9, while GBP2 and S100A8 were up-regulated at both $8 \mathrm{hrs}$ and $24 \mathrm{hrs}$.

\section{b. Induced antinflammatory proteins}

Three TNF- $\alpha$ modulators, TNFAIP2, TNFAIP3 (TNF- $\alpha$ induced proteins 2 and 3 ) and TNIP1 (TNFAIP3 interacting protein 1) were upregulated at 2 hrs. TNFAIP2 may play a pro-angiogenic role, whereas TNFAIP3 interacts with TNIP1 and inhibits TNF-induced NFk-B-dependent gene expression by interfering with RIP- or TRAF2-mediated transactivation signal. The complex acts as an inhibitor of apoptosis, has a role in the function of the lymphoid system and may contribute to the in vivo effects of TNF- $\alpha$.

Two other NFk B inhibitors (NFKBIA and NFKBIE) were upregulated at 2 hrs by 6.2 -fold and 2.4 fold, respectively. These proteins inhibit NFk-B by complexing with and trapping it in the cytoplasm. They may be involved in regulation of transcriptional responses to NFk-B, including cell adhesion, immune and proinflammatory responses, apoptosis, differentiation and growth. IL15 RA (IL15 receptor $\alpha$, 2.2-fold increase at 2 hrs) signals through JakSTAT pathway and plays a role in IL15-mediated T-cell proliferation and differentiation of natural killer cells. Its ligand, IL-15 is a potent inhibitor of TNF-mediated apop- tosis and has a protective effect against E. coli induced shock [25]. IL1RN (IL-1 receptor antagonist; 2.8-fold increase at 2 hrs) is a protein secreted mainly by macrophages that acts as competitive inhibitor of IL-1 $\beta$ binding to its cell-surface receptor. Thus, IL1RN functions as a major naturally occurring anti-inflammatory protein.

\section{c. Suppressed inflammatory genes}

Decreased expression of a group of inflammatory response genes, including TNFRSF8, CXCL5, C7, HLADRB3 was observed at 8 and 24 hrs. TNFSF8/CD30L, a member of the TNF receptor superfamily that regulates gene expression through activation of NFk-B, may play a role in the regulation of cellular growth and transformation of activated lymphoblasts. C7 is a complement component that binds to $\mathrm{C} 5 \mathrm{~b}$ forming the membrane attack complex C5b-7. HLA-DRB3 is a component of the major histocompatibility complex class II and is essential in presenting bacterial antigen to CD4-positive lymphocytes.

Hypoxia, oxidative stress and apoptosis genes

Several genes that have function related to hypoxia and oxidative stress, including HIF1A, TXNRD1, SOD2 and $\mathrm{HP}$, were induced during the time-course of the experiment. HIF1A (2.9-fold increase at 2 hrs) functions as a master transcriptional regulator of the adaptive response 
Table I: Genes up-regulated by sepsis in the lung of the baboons at 2, 8 and $24 \mathrm{hr}$ post $E$. coli challenge

\begin{tabular}{|c|c|c|c|c|}
\hline \multirow[t]{2}{*}{ Gene Accession no. } & \multirow[t]{2}{*}{ Gene Product } & \multicolumn{3}{|c|}{ Fold change compared to control } \\
\hline & & $2 \mathrm{~h}$ & $8 \mathrm{~h}$ & $24 \mathrm{~h}$ \\
\hline \multicolumn{5}{|l|}{ Cytokine or chemokine } \\
\hline NM 002089 & chemokine (C-X-C motif) ligand 2 (CXCL2) & 10.8 & & \\
\hline NM 004591 & chemokine (C-C motif) ligand 20 (CCL20) & 8.3 & & \\
\hline NM 000576 & interleukin I, beta (ILIB) & 4.5 & & \\
\hline NM 005409 & chemokine (C-X-C motif) ligand II (CXCLII) & 4.4 & 10.5 & \\
\hline NM 001565 & chemokine (C-X-C motif) ligand 10 (CXCLI0) & 4.3 & & \\
\hline NM 002982 & chemokine (C-C motif) ligand 2 (CCL2) & 3.5 & & \\
\hline NM 002198 & interferon regulatory factor I (IRFI) & 3.0 & 3.8 & \\
\hline NM 000600 & interleukin 6 (interferon, beta 2) (IL6) & 2.2 & & \\
\hline NM 002189 & interleukin I5 receptor, alpha (ILI5RA) & 2.2 & & \\
\hline NM 002984 & chemokine (C-C motif) ligand 4 (CCL4) & 2.2 & & \\
\hline NM 000759 & colony stimulating factor 3 (granulocyte) (CSF3) & 4.4 & & \\
\hline$\underline{\mathrm{D} 90145}$ & chemokine (C-C motif) ligand 3-like I(CCL3LI) & 2.6 & 3.0 & 2.0 \\
\hline \multicolumn{5}{|c|}{ Cytokine suppression or regulation } \\
\hline$\underline{\times 52015}$ & interleukin I receptor antagonist (ILIRN) & 2.8 & & \\
\hline \multicolumn{5}{|l|}{ Adhesion molecules } \\
\hline NM 001078 & vascular cell adhesion molecule I (VCAMI) & 6.9 & 4.7 & \\
\hline NM 000201 & intercellular adhesion molecule I (CD54), human rhinovirus receptor (ICAMI) & 3.5 & & \\
\hline NM 001816 & carcinoembryonic antigen-related cell adhesion molecule 8 (CEACAM8) & 2.0 & & \\
\hline NM 021219 & junctional adhesion molecule 2 (JAM2) & & 2.0 & 2.3 \\
\hline NM 003370 & vasodilator-stimulated phosphoprotein (VASP) & & 2.3 & 2.1 \\
\hline$\underline{\mathrm{AFI} 39768}$ & $\begin{array}{c}\text { C-type (calcium dependent, carbohydrate-recognition domain) lectin, superfamily } \\
\text { member } 5\end{array}$ & & 2.01 & \\
\hline NM 002999 & syndecan 4 (amphiglycan, ryudocan) (SDC4) & 6.0 & & \\
\hline \multicolumn{5}{|c|}{ Other inflammation-associated genes } \\
\hline NM 004120 & guanylate binding protein 2, interferon-inducible (GBP2) & 10.2 & 16.3 & 2.3 \\
\hline NM 002053 & guanylate binding protein I, interferon-inducible, 67 kDa (GBPI) & 3.8 & 4.5 & \\
\hline NM 006291 & tumor necrosis factor, alpha-induced protein 2 (TNFAIP2) & 3.4 & & \\
\hline NM 006058 & TNFAIP3 interacting protein I (TNIPI) & 2.9 & & \\
\hline NM 006290 & tumor necrosis factor, alpha-induced protein 3 (TNFAIP3) & 2.5 & & \\
\hline NM 003821 & receptor-interacting serine-threonine kinase 2 (RIPK2) & 2.1 & & \\
\hline NM 002964 & SI00 calcium binding protein A8 (calgranulin A) (SI00A8) & 12.0 & 27.5 & 6.2 \\
\hline NM 002965 & SI00 calcium binding protein A9 (calgranulin B) (SI00A9) & 7.7 & 17.5 & \\
\hline NM 007053 & CDI60 antigen (CDI60) & & 2.2 & 2.0 \\
\hline NM 001276 & chitinase 3-like I (cartilage glycoprotein-39) (CHI3LI) & & 3.2 & 2.5 \\
\hline NM 004271 & lymphocyte antigen 86 (LY86) (MD-I) & & & 2.3 \\
\hline NM 001085 & $\begin{array}{c}\text { serine (or cysteine) proteinase inhibitor, clade A (alpha-I antiproteinase, } \\
\text { antitrypsin), member } 3 \text { (SERPINA3) }\end{array}$ & 5.6 & 6.8 & \\
\hline NM 002818 & proteasome (prosome, macropain) activator subunit 2 (PA28 beta) (PSME2) & & & 3.1 \\
\hline NM 004159 & $\begin{array}{c}\text { proteasome (prosome, macropain) subunit, beta type, } 8 \text { (large multifunctional } \\
\text { protease 7) (PSMB8) }\end{array}$ & & & 3.2 \\
\hline \multicolumn{5}{|c|}{ Hypoxia and/or oxidative stress } \\
\hline NM 001530 & $\begin{array}{l}\text { hypoxia-inducible factor I, alpha subunit (basic helix-loop-helix transcription } \\
\text { factor) (HIFIA) }\end{array}$ & 2.9 & 2.5 & \\
\hline NM 003330 & thioredoxin reductase I (TXNRDI) & 2.1 & & \\
\hline NM 000636 & superoxide dismutase 2 , mitochondrial (SOD2) & 12.5 & & 5.0 \\
\hline
\end{tabular}


Table I: Genes up-regulated by sepsis in the lung of the baboons at 2, 8 and $24 \mathrm{hr}$ post $\mathrm{E}$. coli challenge (Continued)

\begin{tabular}{|c|c|c|c|c|}
\hline AK055872 & Haptoglobin (HP) & 33.3 & 24.4 & \\
\hline \multicolumn{5}{|l|}{ Apoptosis } \\
\hline AF070674 & baculoviral IAP repeat-containing 3 (BIRC3) & 2.9 & & \\
\hline NM 015675 & growth arrest and DNA-damage-inducible, beta (GADD45B) & 3.0 & & \\
\hline NM 002727 & proteoglycan I, secretory granule (PRGI) & 2.3 & 2.4 & \\
\hline NM 052889 & CARD only protein (COP) & 9.6 & 11.8 & \\
\hline NM 003311 & pleckstrin homology-like domain, family A, member 2 (PHLDA2) & & 3.1 & \\
\hline NM 005734 & homeodomain interacting protein kinase 3 (HIPK3) & & & 2.0 \\
\hline NM 016426 & G-2 and S-phase expressed I (GTSEI) & & & 2.0 \\
\hline NM 005456 & mitogen-activated protein kinase 8 interacting protein I (MAPK8IPI) & & & 2.3 \\
\hline \multicolumn{5}{|c|}{ Heat shock protein } \\
\hline NM 014365 & heat shock 27 kDa protein 8 (HSPB8) & 3.0 & 2.7 & \\
\hline \multicolumn{5}{|c|}{ Cell proliferation tumor suppressor wound healing process } \\
\hline NM 003311 & pleckstrin homology-like domain, family A, member 2 (PHLDA2) & & & 2.8 \\
\hline NM 021077 & neuromedin $B(N M B)$ & & & 2.0 \\
\hline NM 006069 & murine retrovirus integration site I homolog (MRVII) & & & 2.7 \\
\hline NM 001260 & cyclin-dependent kinase 8 (CDK8) & & & 2.7 \\
\hline NM 003073 & $\begin{array}{l}\text { SWI/SNF related, matrix associated, actin dependent regulator of chromatin, } \\
\text { subfamily b, member I (SMARCBI) }\end{array}$ & & & 2.4 \\
\hline AK055327 & fibroblast activation protein, alpha (FAP) & & & 4.3 \\
\hline NM 005424 & $\begin{array}{c}\text { tyrosine kinase with immunoglobulin and epidermal growth factor homology } \\
\text { domains (TIE) }\end{array}$ & & & 2.9 \\
\hline NM 002408 & $\begin{array}{l}\text { mannosyl (alpha-1,6-)-glycoprotein beta-1,2-N-acetylglucosaminyltransferase } \\
\text { (MGAT2) }\end{array}$ & & & 2.9 \\
\hline NM 020638 & fibroblast growth factor 23 (FGF23) & & & 2.3 \\
\hline NM 006603 & stromal antigen 2 (STAG2) & & & 2.3 \\
\hline NM 005622 & SA hypertension-associated homolog (rat) $(\mathrm{SAH})$ & & & 2.3 \\
\hline$\underline{A B O I 1537}$ & slit homolog I (Drosophila) (SLITI) & & & 2.2 \\
\hline 105158 & carboxypeptidase N, polypeptide 2, 83 kD (CPN2) & & & 2.1 \\
\hline AF339822 & $\begin{array}{c}\text { fms-related tyrosine kinase I (vascular endothelial growth factor/vascular } \\
\text { permeability factor receptor) (FLTI) }\end{array}$ & & 2.2 & 3.2 \\
\hline$\underline{\mathrm{AK} 056352}$ & PR domain containing 5 (PRDM5) & & 2.0 & 2.5 \\
\hline$\underline{A L I \mid 7643}$ & activin $A$ receptor, type IB (ACVRIB) & 2.4 & & \\
\hline \multicolumn{5}{|l|}{ Coagulation } \\
\hline NM 001993 & coagulation factor III (thromboplastin, tissue factor) (F3) & 2.5 & & \\
\hline NM 014059 & response gene to complement 32 (RGC32) & & 3.7 & \\
\hline \multicolumn{5}{|l|}{ Blood pressure } \\
\hline NM 024409 & natriuretic peptide precursor C (NPPC) & & & 2.8 \\
\hline \multicolumn{5}{|c|}{ Energy generation } \\
\hline AF327403 & solute carrier family 25, member 28 (SLC25A28) & 2.1 & & \\
\hline NM 000761 & cytochrome P450, family I, subfamily A, polypeptide 2 (CYPIA2) & & 3.5 & 3.4 \\
\hline AL359600 & ATP-binding cassette, sub-family C (CFTR/MRP), member 5 (ABCC5) & 2.3 & & \\
\hline AF052090 & nicotinamide nucleotide transhydrogenase (NNT) & & & 2.7 \\
\hline NM 004297 & guanine nucleotide binding protein (G protein), alpha I4 (GNAI4) & & & 2.1 \\
\hline \multicolumn{5}{|c|}{ Protein synthesis } \\
\hline$\underline{A L} 161952$ & glutamate-ammonia ligase (glutamine synthase) (GLUL) & 2.1 & & \\
\hline NM 004184 & tryptophanyl-tRNA synthetase (WARS) & 2.1 & 8.0 & 3.4 \\
\hline NM 002954 & ribosomal protein S27a (RPS27A) & & 2.1 & \\
\hline
\end{tabular}


Table I: Genes up-regulated by sepsis in the lung of the baboons at 2, 8 and $24 \mathrm{hr}$ post $\mathrm{E}$. coli challenge (Continued)

NM $013417 \quad$ isoleucine-tRNA synthetase (IARS)

Cation transporter

NM 017964

NM 022154

D31887

Transcriptional regulation

NM 020529

AK026497

NM 004556

NM 013448

NM 015859

NM 004697

NM 005523

NM 006540

NM 012345

NM 004719

NM 0045I4

BG 163465

AK025842 solute carrier family 30 (zinc transporter), member 6 (SLC30A6)

solute carrier family 39 (zinc transporter), member 8 (SLC39A8)

solute carrier family 39 (zinc transporter), member I4 (SLC39A 14)
2.0

$4.4 \quad 3.6$

2.2

nuclear factor of kappa light polypeptide gene enhancer in B-cells inhibitor, alpha (NFKBIA)

YYI transcription factor (YYI)

6.2

2.6

nuclear factor of kappa light polypeptide gene enhancer in B-cells inhibitor, epsilon (NFKBIE)

bromodomain adjacent to zinc finger domain, IA (BAZIA)

general transcription factor IIA, I, 19/37 kDa (GTF2AI)

PRP4 pre-mRNA processing factor 4 homolog (yeast) (PRPF4)

homeo box AII (HOXAII)

nuclear receptor coactivator 2 (NCOA2)

nuclear fragile $\times$ mental retardation protein interacting protein I (NUFIPI)

splicing factor, arginine/serine-rich 2, interacting protein (SFRS2IP)

forkhead box K2 (FOXK2)

I-mfa domain-containing protein (HIC)

nuclear receptor subfamily 2 , group $F$, member 2 (NR2F2)

2.0

2. 1

2.7

2. 1

3.5

3.4

3.3

3.1

2.0

2.0

3.0

$2.5 \quad 3.5$

tubulin, beta, 4 (TUBB4)

RAPIA, member of RAS oncogene family (RAPIA)

2.7

3.7

12.4

apolipoprotein L, I (APOLI)

lipocalin 2 (oncogene 24p3) (LCN2)

lipase, gastric (LIPF)

2. 1

2.3

UDP-N-acetyl-alpha-D-galactosamine:polypeptide $\mathrm{N}$ -

acetylgalactosaminyltransferase I3 (GalNAc-TI3)

heparan sulfate (glucosamine) 3-O-sulfotransferase 3AI (HS3ST3AI)

Heparanase (HPSE)

yrosine kinase with immunoglobulin and epidermal growth factor homology domains (TIE)

mannosyl (alpha-I,6-)-glycoprotein beta-I,2-N-acetylglucosaminyltransferase (MGAT2)

UDP-GIcNAc:betaGal beta-I,3-N-acetylglucosaminyltransferase I (B3GNTI)

Signal transduction

NM 002401

NM 001721

NM 004297

NM 002075

BCOI1671

NM 004125

NM 005279

mitogen-activated protein kinase kinase kinase 3 (MAP3K3)

$\mathrm{BMX}$ non-receptor tyrosine kinase (BMX)

guanine nucleotide binding protein (G protein), alpha 14 (GNAI4)

guanine nucleotide binding protein (G protein), beta polypeptide 3 (GNB3)

guanine nucleotide binding protein (G protein), beta 5 (GNB5)

guanine nucleotide binding protein (G protein), gamma I0 (GNGI0)

G protein-coupled receptor I (GPRI)
3.3

2.0

2. 1

2.1

2.9

2.9

3.0

2.6

2.1

$2.6 \quad 2.2$

2.7

$2.2 \quad 2.5$

3.3 
Table 2: Genes downregulated by sepsis in the lung of the baboons at 2, 8 and 24 hrs post $E$. coli challenge

\begin{tabular}{|c|c|c|c|c|}
\hline \multirow[t]{2}{*}{ Gene Accession no. } & \multirow[t]{2}{*}{ Gene Product } & \multicolumn{3}{|c|}{ Fold change compared to control } \\
\hline & & $2 \mathrm{~h}$ & $6-8 \mathrm{~h}$ & $24 \mathrm{~h}$ \\
\hline \multicolumn{5}{|c|}{ Cytokine, chemokine, inflammation associated gene } \\
\hline NM 001243 & tumor necrosis factor receptor superfamily, member 8 (TNFRSF8) & & 0.23 & 0.18 \\
\hline$\overline{N M} 000014$ & alpha-2-macroglobulin (A2M) & & 0.48 & \\
\hline NM 002994 & chemokine (C-X-C motif) ligand 5 (CXCL5) & & 0.50 & \\
\hline NM 004763 & integrin beta I binding protein I (ITGBIBPI) & & 0.50 & \\
\hline \multicolumn{5}{|l|}{ Immune response } \\
\hline NM 000587 & complement component 7 (C7) & & & 0.32 \\
\hline NM 002125 & major histocompatibility complex, class II, DR beta 3 (HLA-DRB3) & & & 0.33 \\
\hline \multicolumn{5}{|l|}{ Scaffolding protein } \\
\hline NM 001753 & Caveolin I protein (CAVI) & 0.49 & & \\
\hline \multicolumn{5}{|l|}{ Blood coagulation } \\
\hline NM 000361 & Thrombomodulin (THBD) & 0.39 & 0.17 & 0.25 \\
\hline NM 000611 & $\begin{array}{c}\text { CD59 antigen pI8-20 (antigen identified by monoclonal antibodies I6.3A5, EJI6, } \\
\text { EJ30, EL32 and G344) (CD59) }\end{array}$ & & & 0.42 \\
\hline NM 001150 & $\begin{array}{c}\text { alanyl (membrane) aminopeptidase (aminopeptidase } \mathrm{N} \text {, aminopeptidase } \mathrm{M} \text {, } \\
\text { microsomal aminopeptidase) (ANPEP) }\end{array}$ & & & 0.43 \\
\hline \multicolumn{5}{|c|}{ Collagen catabolism, extra cellular matrix } \\
\hline NM 004530 & $\begin{array}{c}\text { matrix metalloproteinase } 2 \text { (gelatinase } \mathrm{A}, 72 \mathrm{kDa} \text { gelatinase, } 72 \mathrm{kDa} \text { type IV } \\
\text { collagenase) (MMP2) }\end{array}$ & & 0.36 & 0.36 \\
\hline$\underline{A L I 10197}$ & tissue inhibitor of metalloproteinase 2 (TIMP2) & & 0.46 & 0.45 \\
\hline NM 001848 & collagen, type VI, alpha I (COL6AI) & & 0.48 & \\
\hline$\overline{N M} 004369$ & collagen, type $\mathrm{VI}$, alpha 3 (COL6A3) & & & 0.30 \\
\hline NM 000362 & $\begin{array}{c}\text { tissue inhibitor of metalloproteinase } 3 \text { (Sorsby fundus dystrophy, } \\
\text { pseudoinflammatory) (TIMP3) }\end{array}$ & & & 0.32 \\
\hline \multicolumn{5}{|l|}{ Cell adhesion, cell migration } \\
\hline NM 001901 & connective tissue growth factor (CTGF) & 0.37 & & \\
\hline$\overline{A Y 027862}$ & upregulated in colorectal cancer gene I (UCCI) & & 0.40 & \\
\hline NM 001769 & CD9 antigen (p24) (CD9) & & 0.30 & \\
\hline NM 002026 & fibronectin I (FNI) & & 0.37 & \\
\hline$\overline{\mathrm{AL050364}}$ & plakophilin 4 (PKP4) & & 0.44 & 0.43 \\
\hline NM 001305 & claudin 4 (CLDN4) & & 0.46 & \\
\hline AF022375 & vascular endothelial growth factor (VEGF) & & & 0.40 \\
\hline NM 013994 & discoidin domain receptor family, member I (DDRI) & & & 0.44 \\
\hline NM 014000 & Vinculin (VCL) & & & 0.50 \\
\hline \multicolumn{5}{|l|}{ Anti-inflammation } \\
\hline AB025432 & delta sleep inducing peptide, immunoreactor (DSIPI) & 0.41 & & 0.39 \\
\hline \multicolumn{5}{|c|}{ Cell growth, proliferation, differentiation, cell cycle } \\
\hline NM 001946 & dual specificity phosphatase 6 (DUSP6) & 0.45 & & \\
\hline NM 002165 & inhibitor of DNA binding I, dominant negative helix-loop-helix protein (IDI) & 0.34 & & \\
\hline NM 006286 & transcription factor Dp-2 (E2F dimerization partner 2) (TFDP2) & & 0.37 & \\
\hline NM 002276 & keratin 19 (KRTI9) & & 0.35 & \\
\hline NM 001424 & epithelial membrane protein 2 (EMP2) & & 0.42 & 0.44 \\
\hline NM 001431 & erythrocyte membrane protein band 4.1 -like 2 (EPB4IL2) & & 0.42 & \\
\hline$\overline{N M} 005610$ & retinoblastoma binding protein 4 (RBBP4) & & 0.45 & 0.45 \\
\hline NM 006407 & cytoskeleton related vitamin A responsive protein (JWA) & & 0.45 & \\
\hline ALI22055 & cyclin-dependent kinase (CDC2-like) II (CDKII) & & 0.45 & \\
\hline NM 016250 & NDRG family member 2 (NDRG2) & & 0.46 & \\
\hline AF368463 & carboxypeptidase M (CPM) & & 0.47 & 0.47 \\
\hline NM 005708 & glypican 6 (GPC6) & & 0.49 & \\
\hline NM 006835 & cyclin I (CCNI) & & & 0.20 \\
\hline $\mathrm{AB} 023182$ & serine/threonine kinase 38 like (STK38L) & & 0.32 & 0.11 \\
\hline AF218029 & $\mathrm{H} 3$ histone, family 3B (H3.3B) (H3F3B) & & & 0.22 \\
\hline NM 001431 & erythrocyte membrane protein band 4.I-like 2 (EPB4IL2) & & & 0.25 \\
\hline NM 006185 & nuclear mitotic apparatus protein I (NUMAI) & & & 0.36 \\
\hline
\end{tabular}


Table 2: Genes downregulated by sepsis in the lung of the baboons at 2, 8 and 24 hrs post $E$. coli challenge (Continued)

NM 001553
NM 001980
AK055976
NM 005778
NM 014399
NM 00679I
Transcriptional regulation
NM 00127I
NM 003924
AJ420430
$\frac{N M 002938}{D 49835}$
$\frac{N M 002624}{N M 003418}$
$\frac{N M 031243}{N M 003151}$
$\frac{A B 058726}{N M 002228}$
$\frac{N M 003205}{N M 031314}$
$\frac{N M 001300}{A L I 33574}$
$\frac{A K 027071}{A J 420430}$

$\begin{array}{cc}\text { insulin-like growth factor binding protein 7 (IGFBP7) } & 0.37 \\ \text { Epimorphin (EPIM) } & 0.38 \\ \text { thymosin, beta 4, X-linked (TMSB4X) } & 0.40 \\ \text { RNA binding motif protein 5 (RBM5) } & 0.41 \\ \text { transmembrane 4 superfamily member I3 (TM4SFI3) } & 0.4 \text { I } \\ \text { mortality factor 4 like I (MORF4LI) } & 0.47\end{array}$

Apoptosis, stress response

chromodomain helicase DNA binding protein 2 (CHD2) paired-like homeobox $2 \mathrm{~b}$ ( $\mathrm{PHOX} 2 \mathrm{~B})$

general transcription factor IIIC, polypeptide $4,90 \mathrm{kDa}$ (GTF3C4) ring finger protein 4 (RNF4)

ras responsive element binding protein I (RREBI) prefoldin 5 (PFDN5)

zinc finger protein 9 (a cellular retroviral nucleic acid binding protein) (ZNF9)

heterogeneous nuclear ribonucleoprotein A2/BI (HNRPA2BI)

signal transducer and activator of transcription 4 (STAT4) PHD finger protein 6 (PHF6)

v-jun sarcoma virus 17 oncogene homolog (avian) (JUN)

transcription factor 12 (HTF4, helix-loop-helix transcription factors 4) (TCFI2)

heterogeneous nuclear ribonucleoprotein $\mathrm{C}(\mathrm{Cl} / \mathrm{C} 2)$ (HNRPC) core promoter element binding protein (COPEB)

TEA domain family member I (SV40 transcriptional enhancer factor) (TEADI) transforming growth factor beta-stimulated protein TSC-22 (TSC22)

general transcription factor IIIC, polypeptide 4, 90 kDa (GTF3C4)

0.38

0.41

0.41

0.44

0.49

0.32

0.34

0.36

0.38

0.34

0.39

0.40

0.43

0.43

0.45

0.45

0.46

0.50

\author{
glutathione peroxidase I (GPXI) \\ apolipoprotein E (APOE) \\ death-associated protein (DAP) \\ glutathione S-transferase M5 (GSTM5)
}

protein phosphatase IA (formerly 2C), magnesium-dependent, alpha isoform (PPMIA)

0.30

0.36

0.40

0.45

0.48
NM 000581

NM 000041

NM 004394

NM 000851

NM 021003

Energy generation or protein synthesis

NM 02004I

ALI36693

NM 002164

AFII370I

NM 021194

NM 000971

NM 015994

NM 001010

NM 001867

NM 020041

NM 001967

NM 001961

NM 001418

NM 003753

NM 001460

AK057575

AK057299

NM 016091

Cardiovascular calcifications NM 000900

matrix Gla protein (MGP)

0.25

0.19

adaptor-related protein complex 2, beta I subunit (AP2BI)

0.38

RAB36, member RAS oncogene family (RAB36)

RAB2, member RAS oncogene family (RAB2)

RAB6A, member RAS oncogene family (RAB6A) sortilin I (SORTI)

0.22

0.31

0.32

0.35

0.38

0.42

0.43

0.43

0.43

0.45

0.46

0.48

0.50

NM 001282

NM 004914

NM 002865

AK057I57

AK000757 
Table 3: Oligonucleotide sequences of the primers used for QRT-PCR

\begin{tabular}{|c|c|c|}
\hline GenBank ID & Gene & Primer pair sequences \\
\hline AF070674 & $\mathrm{BIRC} 3$ & $\begin{array}{c}\text { F 5'-GTG ATG GTG GAC TCA GGT GTT G-3' } \\
\text { R 5'-TCC TGT CCT TTA ATT CTT ATC AAG TAC TCA-3' }\end{array}$ \\
\hline NM052889 & COPI & $\begin{array}{c}\text { F 5'-CAG GCA GTG CGA GGA CAA-3' } \\
\text { R 5'-AGC AAA GCT TGA TTC TGC CTT CT-3' }\end{array}$ \\
\hline NM00I530 & HIFIA & $\begin{array}{l}\text { F 5'-CCA AAT CCA GAG TCA CTG GAA CTT-3' } \\
\text { R 5'-CAT CGG AAG GAC TAG GTG TCT GA-3' }\end{array}$ \\
\hline NM003821 & RIPK2 & $\begin{array}{l}\text { F 5'-ACG TCT GCA GCC TGG TAT AGC-3' } \\
\text { R 5'-GGC AGG CTT CTG TCA TTT GG-3' }\end{array}$ \\
\hline NM002964 & SI00A8 & $\begin{array}{c}\text { F 5'-CAA GTC CGT GGG CAT CAT G-3' } \\
\text { R 5'-AGT ACT TGT GGT AGA CGT CGA TGA TAG-3' }\end{array}$ \\
\hline NM002999 & SDC4 & $\begin{array}{l}\text { F 5'-GGC AAG AAA CCC ATC TAC AAG AA-3' } \\
\text { R 5'-GCC AGT GCC CAC AAG CA-3' }\end{array}$ \\
\hline NM006290 & TNFAIP3 & $\begin{array}{l}\text { F 5'-CTG CCC AGG AAT GCT ACA GAT AC-3' } \\
\text { R 5'-AGG GTC ACC AAG GGT ACA AAA TG-3' }\end{array}$ \\
\hline NM001753 & CAVI & $\begin{array}{l}\text { F 5'-ACA CCG TCT GTG ACC CAC TCT-3' } \\
\text { R 5'-CTG CAA GTT GAT GCG GAC AT-3' }\end{array}$ \\
\hline NM00036I & THBD & $\begin{array}{l}\text { F 5'-CCA GCT CTA CTG GTC TTG TGG AA-3' } \\
\text { R 5'-GAT TAA GGC TAG GCC CTA ATT GG-3' }\end{array}$ \\
\hline $\mathrm{BC} 013835$ & $\beta$-actin & $\begin{array}{l}\text { F 5'-AAG CCA CCC CAC TTC TCT CTA A-3' } \\
\text { R 5'-AAT GCT ATC ACC TCC CCT GTG T-3' }\end{array}$ \\
\hline
\end{tabular}

Abbreviations: F, forward; R, reverse.

to hypoxia. Under hypoxic conditions, HIF1A translocates into the nucleus, where it binds to the hypoxia response element (HRE) of target gene promoters and activates the transcription of over 40 genes involved in oxygen delivery or metabolic adaptation to hypoxia. Upregulation of HIF1A in the lung reflects the strong ischemic condition installed in the early hours post E. coli challenge.

Expression of HP (haptoglobin) was increased 33.3-fold at 2 hrs (second highest induced gene) and 24.4-fold at 8 hrs. HP binds free hemoglobin released from erythrocytes with high affinity and thereby inhibits its oxidative activity. TXNRD1 (thioredoxin reductase; 2.1-fold increase at 2 hrs) is a key enzyme in the regulation of the intracellular redox environment, and protects against oxidative stress. SOD2 (mitochondrial superoxide dismutase; 12.5 and 5fold increase at 2 and 24 hrs, respectively) plays a key role in free radical detoxification by destroying toxic free radicals produced within cells during sepsis.

Among the downregulated proteins involved in oxidation, FABP5 (fatty acid-binding protein-5) was decreased at both 2 hrs and 8 hrs.

With regard to apoptosis, both pro-apoptotic (COP1, GADD45B and RIPK2) and anti-apoptotic (TNFAIP3 and BIRC3) genes were induced in the early stages of sepsis. RIPK2 (CARD-containing IL-1 $\beta$ ICE-kinase) activates both pro-caspase- 1 and pro-caspase- 8 and also potentiates CASP-8-mediated apoptosis.

Moreover, the highest increased gene transcript in our study, IMAGE clone 2363394 (36 and 114 fold at 2 and 8 hrs, respectively) may encode a proapoptotic protein.

Table 4: Gene expression validation using QRT-PCR

\begin{tabular}{|c|c|c|c|c|c|c|c|c|c|}
\hline \multirow[t]{2}{*}{ Gene } & \multicolumn{4}{|c|}{ Microarrays } & \multicolumn{4}{|c|}{ QRT-PCR } & \multirow[t]{2}{*}{ Correlation coefficient } \\
\hline & 0 & $2 \mathrm{hr}$ & $8 \mathrm{hr}$ & $24 \mathrm{hr}$ & 0 & $2 \mathrm{hr}$ & $8 \mathrm{hr}$ & $24 h$ & \\
\hline TNFAIP3 & 9.64 & 23.66 & 17.60 & 10.87 & I & 8.77 & 4.63 & $|5|$ & 0.995 \\
\hline BIRC3 & 7.77 & 22.24 & 14.76 & 7.23 & I & 3.79 & 2.52 & 1.27 & 0.993 \\
\hline RIPK2 & 6.73 & 14.17 & 10.43 & 8.34 & I & 9.48 & 5.65 & 1.24 & 0.978 \\
\hline SDC4 & 4.27 & 25.44 & 6.77 & 7.91 & I & 4.23 & 1.59 & 0.84 & 0.967 \\
\hline THBD & 28.10 & 11.15 & 4.97 & 7.09 & 1 & 0.3 & 0.33 & 0.21 & 0.958 \\
\hline CAVI & $|3.3|$ & 6.65 & 7.15 & 3.44 & I & 0.64 & 0.51 & 0.61 & 0.843 \\
\hline COP & 1.38 & 13.28 & 16.27 & 2.94 & 1 & 1.19 & 3.85 & 0.18 & 0.782 \\
\hline SI00A8 & 9.29 & I I I.85 & 255.40 & 57.64 & I & 9.41 & 8.77 & 4.96 & 0.779 \\
\hline HIFIA & 6.17 & 17.79 & 15.62 & 7.77 & I & 2.13 & 6.66 & 1.13 & 0.602 \\
\hline
\end{tabular}


Searches for known protein domains and functional sequence motifs in the putative open reading frame of this clone, using SMART 4.0[26,27], show perfect homology with a serine-threonine kinase, STK24, also known as STE20-like kinase 3 (Mst3), a less known protein kinase with potential role in the onset of apoptosis[28].

As a general feature, we found that pro-apoptotic genes predominate during early stages, and anti-apoptotic genes predominate during the second stage of sepsis. Five genes encoding apoptosis inhibitors (TNFAIP3, BIRC3 HIPK3, MAPK8IP1 and LCN2) were up-regulated at different time points while one gene, DAP, a positive-regulator of apoptosis was down-regulated.

\section{Cell adhesion and extracellular matrix (ECM) molecules}

During the inflammation, adhesion molecules are involved in the transmigration of leukocytes through the vessel wall. Beside the two well characterized adhesion proteins ICAM1 and VCAM1, CEACAM8 (CD67, a GPIanchored protein exclusively expressed on neutrophils and eosinophils), and SDC4 (syndecan 4, a heparan-sulphate proteoglycan) were also up-regulated early in the inflammatory response. Two other adhesive molecules, VASP and CLECSF5, were up-regulated at later stages (8 and $24 \mathrm{hrs}$ ). VASP is an actin-associated protein that functions in cytoskeleton remodeling during leukocytetransendothelial migration. CLECSF5 is a lectin expressed on macrophages that may be involved in proinflammatory activation of myeloid cells via TYPO-BP mediated signaling.

Decreased mRNA levels of another group of genes (CTGF, UCC1, PKP4, TNS, CD9, FN1, VCL, ITGB1BP1, claudin 4, and VEGF) were observed at $8 \mathrm{hrs}$ and $24 \mathrm{hrs}$. CTGF is a major connective tissue mitoattractant secreted by endothelial cells. UCC1 is a calcium-dependent cell adhesion molecule, similar to the protocadherins and ependymins. PKP4 is a component of desmosomes and other adhesion plaques, and is involved in regulating junctional plaque organization and cadherin function. TNS (tensin1 ) is localized to focal adhesions, and is thought to play a role in cell migration by linking signal transduction pathways to the cytoskeleton. CD9 is a tetraspanin family member that makes complexes with integrins and other tetraspanins, modulates cell adhesion and migration and also mediates platelet activation and aggregation. FN1 (fibronectin) is a dimeric/multimeric glycoprotein present in plasma, ECM and on the cell surface, and is involved in cell adhesion and migration, wound healing, blood coagulation, and host defense. VCL (vinculin) is a cytoskeletal protein associated with cell-cell and cellmatrix junctions, where it is thought to function as one of the several proteins involved in anchoring $\mathrm{F}$-actin to the membrane. ITGB1BP1 may play a role in the recruitment of $\beta-1$ integrins to the focal contacts during integrindependent cell adhesion. Genes with decreased expression at $8 \mathrm{hrs}$ and $24 \mathrm{hrs}$ include matrix proteins (collagen VI) or metalloproteainases and their inhibitors (MMP2, TIMPs 1 and 2).

Regulation of cell growth, transcription and membrane transport Except for ACVR1 (activin receptor 1B) that was induced at 2 hours, most of the genes involved in growth regulation and recovering processes were upregulated during the second stage of sepsis. Genes encoding proteins that are involved in cell cycle (CDK8, SMARCB1, STAG2), cell migration (SLIT1), cell proliferation (PHLDA2, NMB, FAP, TIE), tissue regeneration and remodeling (FGF23), and protein glycosylation (MGAT2, HPSE, B3GNT1, HSE3ST3A1, LARGE, GLANT13) were increased almost exclusively at 24 hrs (Table 2).

Most of the genes encoding for transcriptional regulation factors, including transcription factors (HOXA11, FOXK2), transcription repressors (HIC), splicing factors (PRPF4, SFRS2IP), and nuclear receptors co-activators (NCOA2, NUFIP1, NR2F2), were also up-regulated at 24 hrs. However, increased expression of transcriptional factors NFKBIA and NFKBIE (NFKB negative regulators), as well as of GTF2A1 (general transcriptional factor IIA) are detected only at 2 and 8 hrs, respectively.

STAT4, a major transcriptional co-regulator of several signaling pathways (STAT, p53, wnt and steroid hormone signaling) was down-regulated at $24 \mathrm{hrs}$.

Several ion transporters, including zinc transporters and members of the solute carrier (SLC) families (SLC25A28, SLC30A6, SLC39A8, and SLC39A14) are increased during the early stages of $E$. coli sepsis. The expression of other transporters, including SLC2A9 (glucose transporter) and SLC25A3 (mitochondrial phosphate carrier) was decreased at $8 \mathrm{hr}$ and $24 \mathrm{hrs}$.

A decreased expression of several genes involved in the intracellular trafficking of proteins was observed at $24 \mathrm{hrs}$. These included adaptor-related protein complex $2 \beta-1$ subunit (AP2B1), a component of the coat surrounding transport membrane vesicles, three members of RAS oncogene family (RAB2, RAB6A and RAB36), and sortilin 1. The latter is required for the formation of a specialized storage vesicle for the glucose transporter SLC2A4/GLUT4.

\section{Clustering of gene expression patterns induced by sepsis} Pathologic processes in sepsis fluctuate significantly. Understanding this complexity may allow enhanced pharmacologic intervention. Using gene clustering methods demonstrated that gene expression also changes over time in complex manner. A gross assessment of expression 
kinetics could be made from a heat-map representation of differentially expressed genes from all time points. Three basic expression patterns were observed (Fig. 2). About $40 \%$ of the genes were down regulated, $25 \%$ of genes were up regulated and $15 \%$ were up and then down regulated. A list of the genes presented in this map is provided as Supplementary table 1 .

A more detailed analysis of expression changes was done using a clustering algorithm that identifies clusters of genes that change in expression in a highly correlated manner. Ten clusters of genes were identified based on their expression dynamics during the time-course of the experimental sepsis (Fig. 2; and Additional file 1). Gene clusters 1 to 4 contain genes that are downregulated by sepsis (Fig. 2). Cluster 1 groups 9 genes that reach a maximum decrease at $8 \mathrm{hrs}$ and recover at $24 \mathrm{hrs}$. These genes are involved in cell cycle (TFDP2, GPC6), tight junctions (CLDN4), and cell structural integrity (KRT19).

Cluster 2 consists of 34 genes that are decreased at 2-8 hrs and stay decreased at $24 \mathrm{hrs}$. These genes are involved in complement and coagulation cascades (THBD, A2M), cell adhesion and migration (MMP2, UCC1, CTGF, PKP4, TNS, ) and scaffolding and signaling (CAV1; caveolin 1). Cluster 3 is the largest (118 genes) and includes genes involved in inflammation (TNFRSF8, C7, CXCL5, ITGB1BP1, STAT4), apoptosis and stress (GSTM5, GPX1, DAP), extracellular matrix (COL6A1, TIMP2, TIMP3), and cell adhesion and migration (CD9, FN1, and VCL). Genes in cluster 3 steadily decreased during the time course of the experiment, except for VEGF, which increased at 2 hrs then was gradually down-regulated.

Clusters 5 to 10 include genes that are upregulated by $E$. coli challenge, as compared to controls. Genes in cluster 5 are upregulated between 2 and 8 hrs, then decrease at 24 hrs. Genes in cluster 6 are steadily upregulated during the time-course of the experiment, while those in cluster 7 are strongly upregulated during the mid and second stage. Clusters 6 and 7 consist of 34 genes each that reach maximal expression at $24 \mathrm{hrs}$. Genes in these groups have biological functions in cell proliferation and wound healing (FAP, STAG2, and FLT1 in cluster 6; FGF23 and TIE in cluster 7), signal transduction (MAP3K3, GNA14, GPR1, GNG10 and MAPK8IP1 in cluster 6; BMX, NMB and NR2F2 in cluster 7), protein glycosylation (HPSE and HS3ST3A1 in cluster 6; B3GNT1 and GALNT13 in cluster 7), blood pressure regulation (NPPC), energy pathway (NNT and GNA14), and inflammation (MD1, lymphocyte antigen 86).

Cluster 8 contains genes that peak at 2 hrs, and cluster 9 genes peak at $8 \mathrm{hrs}$ and then gradually decrease. The genes in cluster 10 peak at 2-8 hrs and generally stay up for the

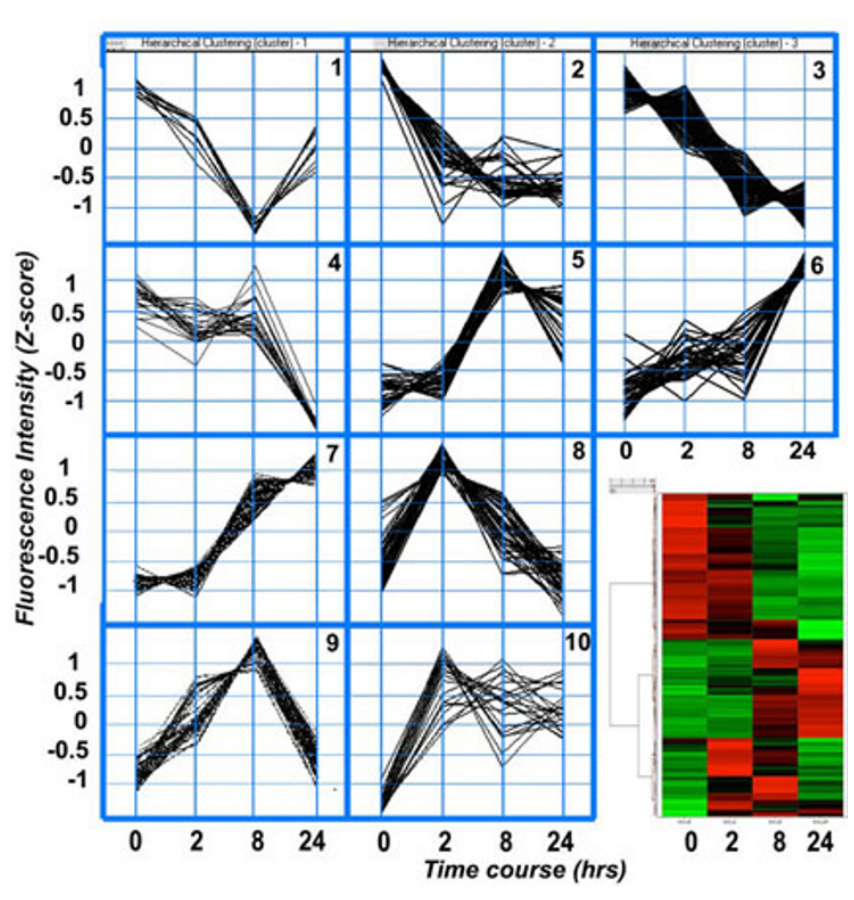

Figure 2

Ward's hierarchical cluster analysis of time-dependent gene expression patterns in the lungs of $E$. coli challenged versus control baboons. a: Differentially expressed genes were used in the hierarchical clustering analysis by Spotfire DecisionSite 8.I (Spotfire, Sommerville, MA). Wards's method computes cluster proximity by the squared Euclidean distance between the gene cluster mean profiles. With this method ten clusters of genes with similar profiles were generated. See the Additional file I for a list of genes grouped in each cluster. b: Heat map of hierarchical clustering analysis. The hierarchical clustering process is represented as a tree, or dendrogram, where each step in the clustering process is illustrated by a join of the tree. Red color indicates a Z-score I, green color indicates a Z-score equal to $-\mathrm{I}$. The colors between red and green indicate Zscores between I and -I.

rest of the time. Cluster 8 contains mainly early responsive genes, such as cytokines and chemokines (IL6, CXCL2, CCL2 (MCP-1), IL1B, CCL20, IL1RN, CCL4), inflammatory response genes (RIPK2, SDC4, TNFAIP2, TNIP1, NFKBIE, TNFAIP3, ICAM1, VCAM1, CEACAM8, NFKBIA), stress response (TXNRD1, HIF1A, HP) and apoptosis-associated genes (BIRC3, GADD45B). Cluster 9 contains mid-stage induced genes, including many cytokines and inflammatory response genes, such as CXCL10, CXCL11，CSF3，S100A8， CLECSF5，S100A9, IRF1, PSMB8, PSME2, GBP1 and GBP2. While the posttranscriptional effects of these patterns are more relevant for designing therapy, it is clear from this analysis that transcriptional regulation itself is equally complex, and perhaps models one causal aspect of disease pathology. 


\section{Pathway analysis}

Differentially expressed genes were analyzed using pathway analysis software, which characterizes networks of genes with common regulatory and signaling capacity. This allows identification of potentially relevant molecular processes by visual inspection. Regulatory and signaling networks of genes were created from the differentially expressed genes at the $2 \mathrm{hrs}, 8 \mathrm{hrs}$ and $24 \mathrm{hrs}$ time points. For each time point several major molecular pathways were identified. The lists of genes in each network and their scores are summarized in the Additional files 2, 3, 4 .

Moreover, this type of analysis underscores the complex evolution of molecular processes that occurs in sepsis. At 2 hrs the most significant (score 78) network contained 35 differentially expressed genes. This pathway consists mainly of pro-inflammatory genes responsive to IL-1 $\beta$ and IL-6 (Fig. 3a). Three other pathways identified at 2 hours were involved in cell movement, cell proliferation and death, cell signaling and molecular transport [see Additional file 2].

At 8 hrs, 8 networks with more than 10 focus genes were found to be highly significant [see Additional file 3). These networks were associated with several functions related to tissue regeneration and homeostasis, including cell migration, proliferation, membrane transport, cellular assembly and organization. The network depicted in Fig. 3b has the highest score (26) and highest number of focus genes ( 18 genes; 7 up- and 11 down-regulated), and is involved in cell movement, cell-cell signaling and interaction.

At 24 hrs, 10 networks with more than 10 focus genes were detected [see Additional file 4]. The highest score belonged to a network with functions in cardiovascular development and organismal survival (Fig. 3c). Similar to the 8 hrs time-point, the major networks expressed at 24 hrs are involved in tissue regeneration and homeostasis [see Additional file 4].

\section{Cytokine profiling in lung and plasma}

Since it has been suggested that serum cytokine levels may not be representative of local tissue inflammation, we have measured the cytokine levels in lung homogenates in parallel with the plasma (Fig. 4). In the lung, most of the cytokines assayed (TNF- $\alpha$, IL1- $\beta$, IL- 4 , IL- 6 , IL-8, and GMCSF) show maximum levels at 2 hrs after which they gradually decrease, except for IL-10, which peaks at $8 \mathrm{hrs}$. The plasma levels of these cytokines show a bimodal pattern, with a first peak at 2 hrs followed by a second peak at 24 hrs, except for IL-4, which peaks at 8 hrs. Most cytokine levels are higher in plasma than in lung tissue, with the exception of IL-8, which is over 5 fold higher in the lung than in the plasma, and IL-10, which is almost 2 times higher in the lung at 8 hrs than in the plasma. Our data demonstrate the existence of a lung specific cytokine profile, and suggest that serum cytokine levels may not be representative of local tissue inflammation and end-organ damage.

\section{Structural changes of the lung during E. coli sepsis}

Histology and electron microscopy analysis demonstrate gradual alteration of lung morphology. In contrast to the normal architecture of the alveolar septae observed in healthy baboons (Fig. 5a), marked accumulation of inflammatory cells (especially neutrophils) within the lung microvasculature was observed at 2 hrs (Fig. 5b). Intermediate and late stages displayed various degrees of interstitial edema due to capillary leakage into the alveolar space, increased accumulation of macrophages, fibroblasts and collagen deposition (Fig. 5c).

\section{Discussions and Conclusion}

Sepsis is a complex, multifactorial inflammatory dysregulation occurring when the host is unable to effectively control a bacterial infection. The disease eventually affects the lungs, heart, liver and kidneys, through multiple effects on endothelial, epithelial and immune cells. Despite progress in understanding its pathophysiology, sepsis is still a common disease with rising incidence and mortality. Many promising therapeutic approaches that were effective in animal studies failed to show similar benefit in human clinical trials[29]. This may be due to the fact that rodent models do not faithfully recapitulate the human disease, or to improper staging of the disease in animal models as compared with humans. Advances in understanding the sequence of events and their specific biomarkers during the progressive stages of sepsis would increase the ability to define appropriate therapeutic targets and to define human populations for successful therapeutic interventions. Our group has thoroughly investigated the changes in plasma proteins during the two-stage compensated response to sublethal inflammatory E. coli challenge[30]. The first-stage of events occurred within the first 4-6 hrs post-infusion and was characterized by massive production of vasoactive peptides and cytokines, closely followed by activation of coagulation, margination and activation of neutrophils, release of sympathomimetic effectors, and leading to a transient microvascular vasoconstriction and ischemia[17]. The secondstage events occur after 12 hrs post challenge and include post reperfusion oxidative stress, complement activation, and a second round of hemostatic activity[17]. However, the underlying sequence of changes in gene expression after $E$. coli challenge at tissue level is unknown.

A major complication in sepsis is the progressively impaired lung function, which often leads to acute lung injury. Our aim was to understand the dynamics of the 


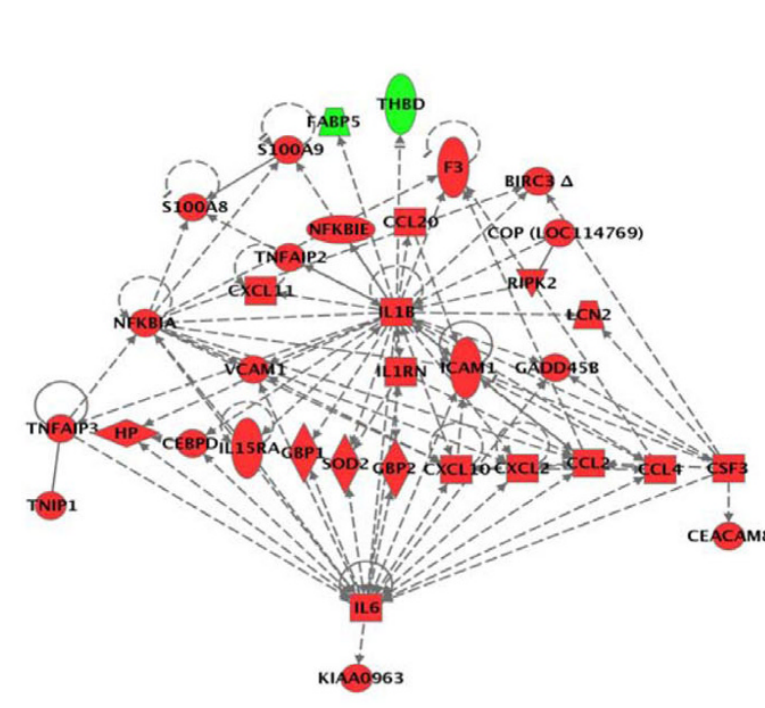

a: 2 hrs; IPA Network 1

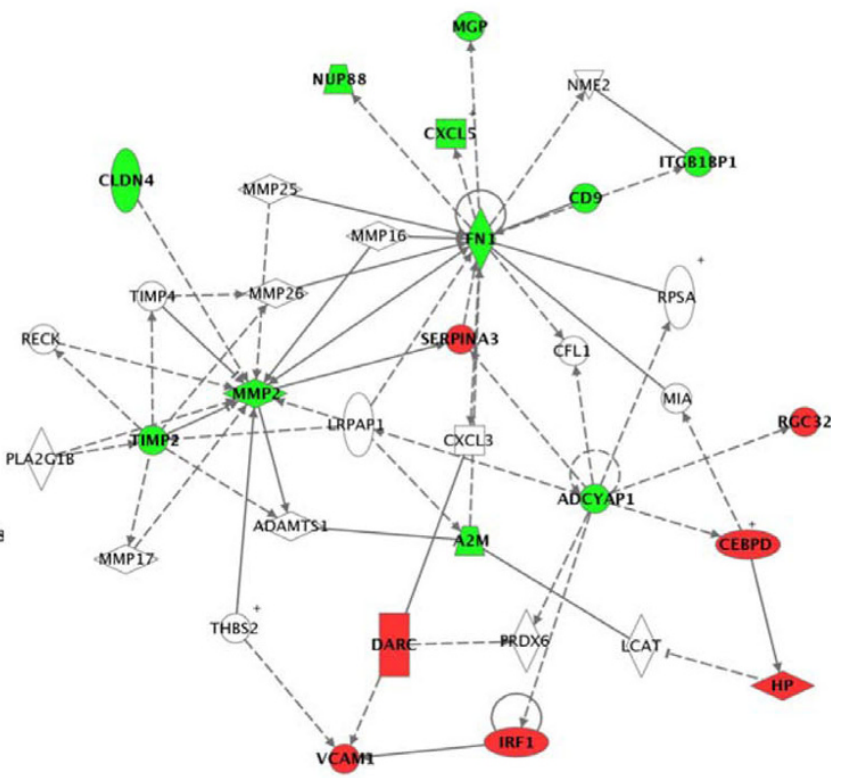

b: 8 hrs; IPA Network 1

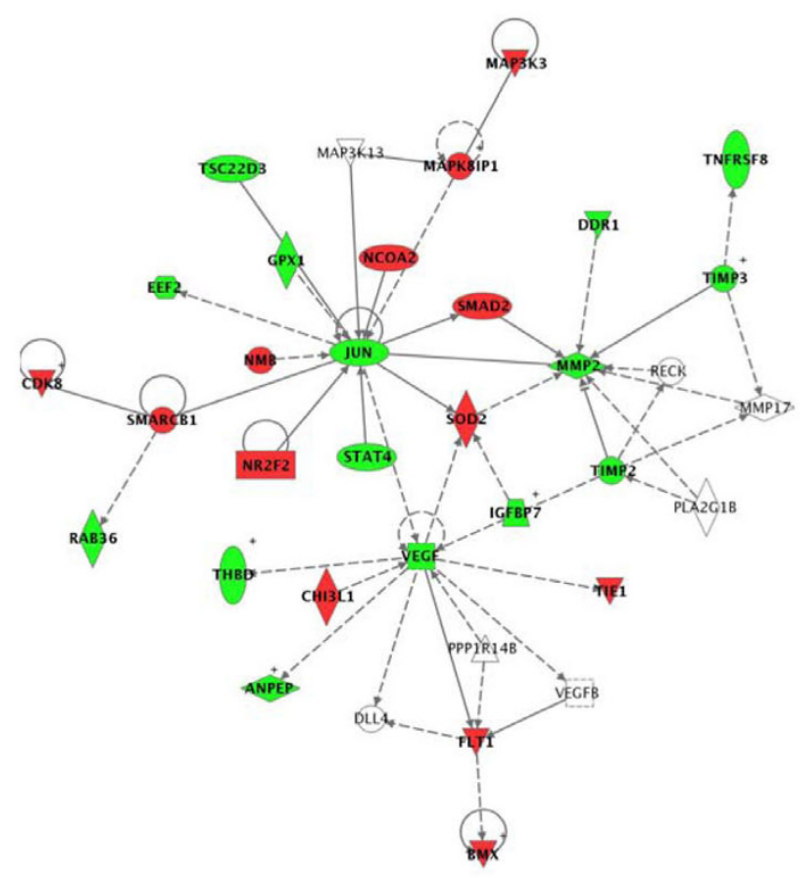

c: 24 hrs; IPA Network 1

Figure 3

Ingenuity Pathway Analysis (IPA) of the differentially expressed genes at different time points after E. coli challenge. Green indicates down-regulation and red indicates up-regulation. In this map all genes shown were statistically different from the control. A line indicates that two gene products show binding, a line terminated by arrow indicate that one gene product acts on the other gene product, and the plus sign indicate that other networks contain the gene product. The networks with the highest score in each time-point group are illustrated. a: IPA network I at 2 hrs; b: IPA network I at 8 hrs; c: IPA network I at 24 hrs. See the Additional files 2, 3, 4 for lists of genes involved in each network. 

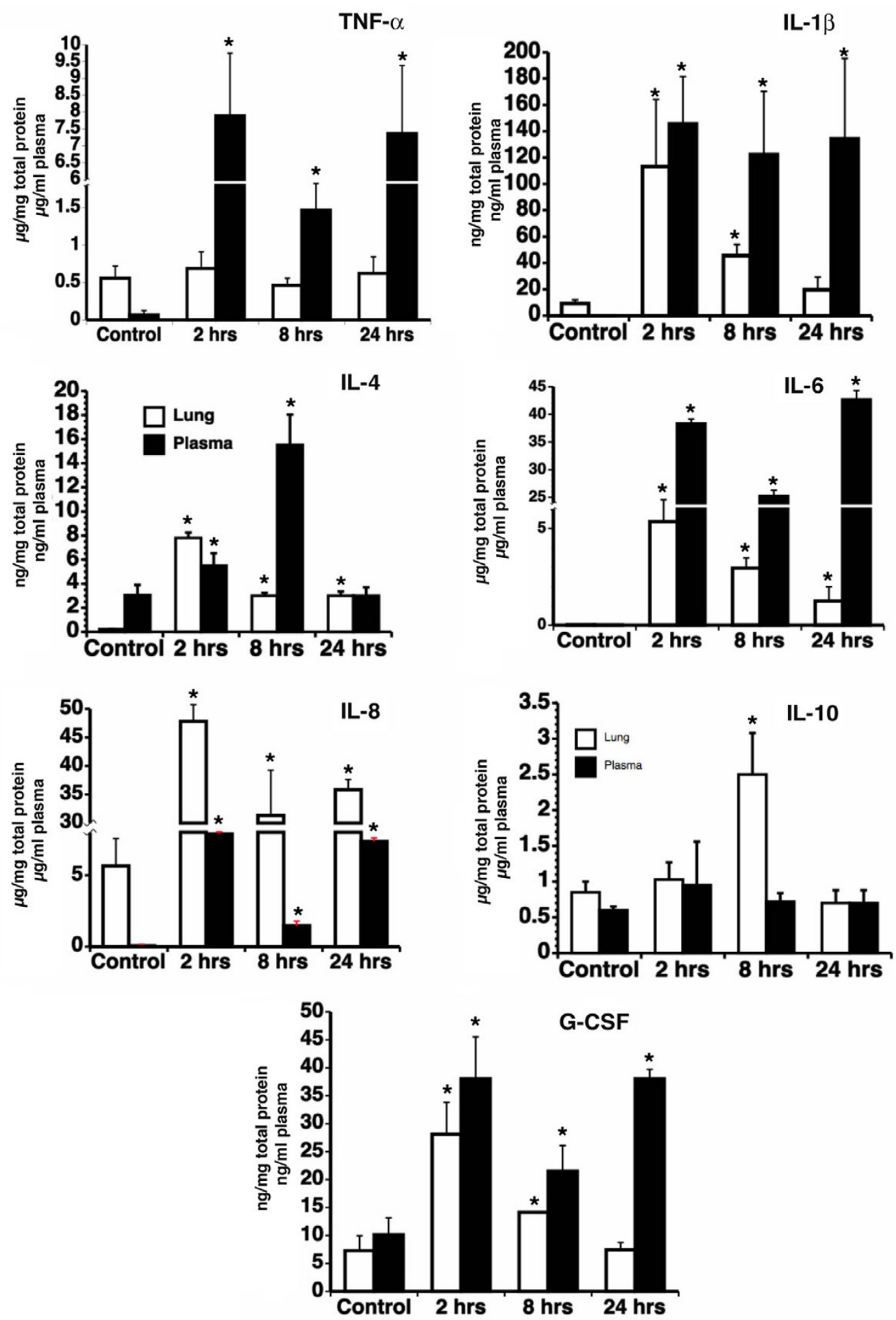

Figure 4

Cytokine quantitation in lung extracts and plasma of $E$. coli challenged baboons. TNF- $\alpha$, IL-I $\beta$, IL-4, IL-6, IL-8, IL-I0 and G-CSF were assayed in lung lysates and plasma using a multiplex assay, as described in the Methods section. The values represent calculated as ratio per total protein in cell lysates or per $\mathrm{ml}$ of plasma, and presented as mean $\pm \operatorname{SD}(n=3)$. Asterisks $(*)$ indicate $p<0.05$ t-test values for lung and plasma samples of challenged animals (2, 8 and 24 hrs post $E$. coli infusion) vs. non-challenged controls. 

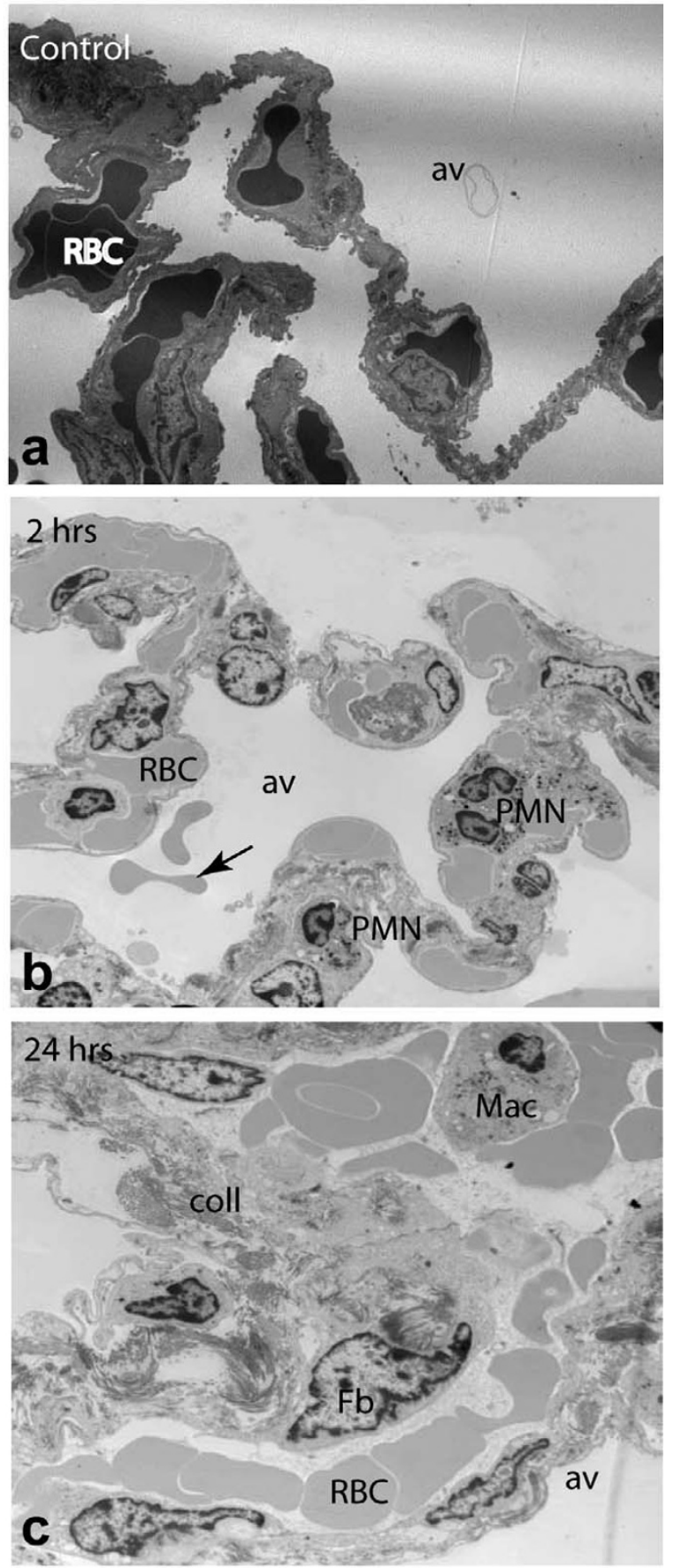

Figure 5

Electron microscopy analysis of structure changes in E. coli challenged baboon lung. a: normal architecture of the alveolar septae in healthy baboons; b. accumulation of neutrophils (PMN) and the presence of intra-alveolar bleeding erythrocytes (arrow) can be observed at 2 hrs; c: the increased accumulation of macrophages, fibroblasts and collagen deposition at 24 hrs. av, alveola; coll, collagen; Fb, fibroblasts; Mac, macrophages; RBC, red blood cells. Magnification: $\times 7000$. specific changes in the transcriptional program of the lung during the two stage inflammatory response to $E$. coli sepsis in baboons. The three time points selected, 2, 8 and 24 hours, represent the first, the transitional and the second stage of the pathophysiological response to E. coli sepsis. Identification of molecular fingerprints of the lung during sepsis may facilitate the development of new approaches for early diagnosis, treatment or prevention.

The baboon genome is not known yet; however, since the similarity between the human and baboon genomes is higher than 94\%[22,31], and previous publications have demonstrated that human DNA arrays can be effectively cross-hybridized with monkey $\mathrm{CDNA}[22,23,31,32]$, we used a human genome-specific oligonucleotide microarray to hybridize the baboon cDNA. We assume that the human probes that are hybridized by the homologous baboon cDNA provide valid information, while the nonhybridized probe-sets can reflect either the absence of the transcript or differences in the baboon sequence that prevent hybridization. However, the use of pathway analysis tools allows for the identification of networks of genes that are known to interact with each other. This procedure therefore provides confidence in the selected genes as well as clues to what other genes may be regulated but not identified as being significant by the microarray analysis.

We acknowledge two inherent limitations of our study. First, as we have extracted total RNA from whole lungs, our preparation contains transcripts originating from different cell types, therefore the spatial and cellular information as to the origin of the signal is lost. To partially overcome this limitation, we always have collected the tissue from the same region of the lung both for RNA extraction and for histological and ultrastructural analysis. The second limitation affects all gene array studies and derives from the fact that one gene can encode multiple spliced forms of transcripts, and further, the translated proteins undergo various post-translation modifications.

\section{Sequential induction of inflammatory and immune response genes}

Sepsis involves an early strong activation of proinflammatory networks, triggered by the exposure of the host to LPS and other bacterial products. Most of the 35 genes that were induced by $E$. coli at 2 hrs belong to the inflammatory pathway and are regulated by, or interact with IL- $1 \beta$ and IL-6. Except for decreased THBD and FABP5, the remaining 33 genes are upregulated at this time-point.

It is clearly demonstrated both in humans and animal models that cytokine production/release is a sequential process. First, LPS induces proximal cytokines (TNF- $\alpha$, IL$1 \beta$ ) via the activation of NF-kB pathway[33], and these two cytokines seem to mediate most of the patho-physio- 
logical disturbances characteristic to sepsis. TNF- $\alpha$ is very rapidly (within 60-90 $\mathrm{min}$ ) induced when the inflammatory response is initiated. As our earliest time point was 2 hrs, no up-regulation of TNF- $\alpha$ mRNA was detected. However, we have detected elevated levels of TNF- $\alpha$ in plasma of $E$. coli challenged baboons, at all three time-points, as well as the mRNA of a variety of inflammatory mediators known to be regulated by TNF- $\alpha$, including chemokines (CXCL2, CXCL10, CXCL11, CCL2, CCL4, CCL20), adhesive molecules (VCAM1, ICAM1, CEACAM8), cytokines and their receptors (IL-1 $\beta$, IL-6, IL-1RN, IL-15RA, CSF3), TNFAIP2, TNFAIP3, TNIP1, the oxidative stress response gene HP, SOD2 and other inflammatory response genes S100A8, S100A9, NFKBIA, NFKBIE, GBP1, GBP2.

Next, proximal cytokines stimulate the production of distal cytokines IL-6 and IL-8 and/or anti-inflammatory mediators like IL-10[34].

IL-6 regulates the expression of complement components on endothelial cells and enhances cell function and production of pro-inflammatory mediators[35]. IL-8 is a potent activator and chemoattractant for neutrophils and it is thought to mediate neutrophilic infiltrates in the lung. In patients, high levels of IL-8 in broncho-alveolar lavage fluid were found to be predictive for the development of ARDS and were associated with high mortality[36]. In addition, IL-1 $\beta$ and TNF- $\alpha$ increase the expression of specific subsets of chemokines and adhesion molecules that appear to be involved in the pathogenesis of lung injury. Expression of E-selectin and ICAM1 on the pulmonary endothelium and alveolar epithelial cells enhances the adhesiveness of neutrophils to endothelial cells, facilitates transmigration into interstitial and distal airways and mediates the development of acute capillary leaks[35]. Chemokines are involved in immune and inflammatory responses where they act primarily as chemoattractants and activators of specific leukocyte subsets. CC chemokines positively enhance macrophage function, leading to enhanced generation of CXC chemokines that results in chemoattraction of neutrophils into lung interstitial and alveolar compartments[35]. We have detected increased gene expression of three CX and four CC chemokines. CXCL2 (MIP-2 $\alpha$ )-the highest expressed chemokine (10.8-fold at $2 \mathrm{hrs}$ )- is produced by activated monocytes and neutrophils and expressed at sites of inflammation, and is also induced in vitro by LPS treatment of bronchoalveolar cells[37]. Two interferon $\gamma$ induced CX chemokines were detected. CXCL10 (IP-10; 4.3-fold at $2 \mathrm{hrs}$ ) is chemotactic for monocytes and Tymphocytes, and CXCL11 (IP-9; 4.4-fold at 2 hrs and 10.5fold at $8 \mathrm{hrs}$ ) is an attractant for interleukin-activated $\mathrm{T}$ cells but not for unstimulated $\mathrm{T}$ cells, neutrophils or monocytes. CXCL11 induction by IFN- $\gamma$ is enhanced by TNF- $\alpha$ in monocytes, fibroblasts and endothelial cells.
Surprisingly, while several IFN- $\gamma$-induced genes were identified in this study, IFN- $\gamma$ itself has not been detected. It is known from previous studies published by this lab that plasma levels of IFN- $\gamma$ peak after 8 hrs post-challenge[38]. The lack of IFN- $\gamma$ message could reflect a mismatch with the human probe, or a low content of the lung in t cells and antural killer cells, which are the main IFN $\gamma$-producing cells.

Among the CC chemokines, CCL20 (MIP 3 $\alpha$; over 8-fold increase at 2 hrs) attracts lymphocytes and, slightly, neutrophils, but not monocytes. It is induced by LPS, TNF- $\alpha$, and IFN- $\gamma$ and possesses antibacterial activity against $E$. coli. CCL3L1 is the only chemokine that was found increased at all three time-points. This is a chemotactic agent for lymphocytes and monocytes and a known inhibitor of HIV infection, but to date, no involvement in E. coli sepsis has been reported. CXCL5 (LIX or ENA-78), an attractant and activator of neutrophils, was the only downregulated chemokine. Interestingly, this chemokine was the highly expressed in a mouse model of LPS induced acute lung injury[6]. The divergent expression patterns for CXCL5 could reflect species-specific differences, or distinct responses to live bacteria vs. LPS challenge.

Two other inflammatory proteins, S100 calcium binding protein, S100A8 (calgranulin A) and S100A9 (calgranulin $\mathrm{B})$, were among the highest expressed genes. S100A8 was increased by 12.0, 27.5 and 6.2-fold at 2 hrs, 8 hrs and 24 hrs, respectively, while S100A9 was up-regulated 7.7 and 17.5-fold at 2 and 8 hrs, respectively. S100A8 and S100A9 are proinflammatory neutrophil modulatory proteins. These proteins are found in the cytosol of neutrophils, monocytes and differentiated macrophages in inflamed tissues[39] as well as in the extracellular milieu during inflammatory conditions $[40,41]$, where may play role in the recruitment and migration of neutrophils [42]. These two calgranulins play an important signaling role by inducing NF-kB activation and increased phosphorylation of p38 and p44/42 MAP kinases. Similar to another member of the calgranulin superfamily, S100A12, also referred to as ENRAGE, S100A8 and S100A9 interact with cellular RAGE on endothelium, mononuclear phagocytes, and lymphocytes triggering cellular activation, and generation of key proinflammatory mediators[43]. High levels of serum S100A8 and S100A9 were reported in chronic inflammation disorders, like rheumatoid arthritis, inflammatory bowel disease $[44,45]$, bronchitis and tuberculosis $[46,47]$. The increased expression of calgranulins may reflect the large number of neutrophils and macrophages that accumulate in the lung, and may serve as additional molecular markers of early inflammatory response to infection. 
GBP1 and GBP2 are two members of the guanylate-binding protein (GBP) family of GTPases that are strongly induced by IFN- $\tilde{\gamma}$ and other inflammatory cytokines. GBP-1 mediates the inhibition of endothelial cell proliferation by inflammatory cytokines[48]. GBP-2 is expressed by macrophages and has mainly a vesicular location. Both proteins are considered as reliable markers of inflammatory phenotype for endothelium and macrophages, respectively[49,50]. GBP2 may also stimulate fibroblast proliferation and fibrosis[51].

Consistent with prior studies[52], we found that early proinflammatory response to sepsis in the lung is followed by the transition to an anti-inflammatory state. This is achieved by marked production of anti-inflammatory mediators (DISIP, IL1RN, IL15RA, TNFAIP3, NFKBIA and NFKBIE) and downregulation of proinflammatory genes during the second stage of the disease (TNFRSF8, CXCL5, C7, ITGB1BP1).

Our data demonstrating that IL-1 receptor antagonist is upregulated in the early stages support a tight regulation of pro- and anti-inflammatory responses in the lung. The resulting balance may determine the outcome of the disease, as recent reports demonstrate an increased ratio of IL-1 $\beta$ to IL-1 receptor antagonist in patients with established ARDS[53,54]. During the predominantly antiinflammatory stages, monocytes are deactivated, resulting in decreased HLA-DRB3 and consequent reduced antigen presentation, which is proposed as a major feature of sepsis-induced immunodepression[55]. Our data support a transcriptional down-regulation of a panel of genes required for MHC II-restricted antigen presentation that may occur in the course of septic shock[56]. In macrophages, DISIP (delta sleep peptide, immunoreactor) plays a role in the anti-inflammatory and immunosuppressive effects of IL-10 by inhibiting NFKB1 nuclear translocation. Two important anti-inflammatory mediators, IL-4 and IL-10 showed no change at mRNA level, but were detected by ELISA at 2 and 8 hrs respectively. This discrepancy may reflect sequence differences between human and baboon cDNA.

\section{Coagulation}

Thrombomodulin (THBD) is one of few genes that are decreased at all 3 time points in this study. THBD is part of the anticoagulant pathway that mediates the activation of zymogen Protein C to activated Protein C (APC). APC is an enzyme that inhibits thrombin generation by degrading clotting factors Va and VIIIa, and regulates inflammation by inhibiting leukocyte activation, thereby reducing organ injury and microthrombus formation in sepsis. It is well documented that sepsis promotes procoagulant activity by strong upregulation of tissue factor
(F3) paralleled by a decrease of tissue-associated THBD due to TNF-dependent shedding into the plasma[57], leading to the development of DIC associated with sepsis.

\section{Hypoxia, oxidative stress and apoptosis}

Oxidative stress occurs when a homeostatic balance between the formation of reactive oxidizing oxygen species and their removal by endogenous antioxidant scavenging compounds is disrupted[58]. Sepsis may lead to oxidative stress either by excessive production of reactive oxygen species including superoxide, hydrogen peroxide and hydroxyl radicals and/or by inadequate antioxidative defense, including superoxide dismutase (SOD), catalase, vitamins $\mathrm{C}$ and $\mathrm{E}$, and reduced glutathione[59]. One symptom of severe sepsis is the impaired ability of tissue to extract oxygen from the blood[60], leading to anaerobic metabolism.

Unexpectedly, we found that haptoglobin mRNA was highly increased in the lung of septic baboons. This plasma protein, normally produced by the liver, binds any excess free iron, preventing bacteria from using the iron to grow. In hemolysis, hemoglobin binds to haptoglobin to form a complex that will be absorbed, thus preventing its excretion into urine. Increased haptoglobin production by the lung is a novel finding, and may be an adaptive response to bacterial infection or may be partially due to the limited hemolysis caused by sepsis. Two stress-inducible proteins, SOD2 and TXNRD-1 are major scavengers of reactive oxygen species[61] but also have anti-apoptotic effects[62]. SOD2 is one of the key defense enzymes induced in host to destroy dangerous reactive oxygen species, such as superoxide radical $\left(\mathrm{O}^{2-}\right)$ formed in the mitochondria as a byproduct of electron transport. It was reported that TNF- $\alpha$ increased the level of thioredoxin and SOD2 by a NF-kB dependent mechanism[63] and the overexpression of SOD2 prevents apoptosis induced by several oxidative stress inducers including TNF- $\alpha$ [64]. The dramatic upregulation of these genes at $2 \mathrm{hrs}$ may reflect their role in counteracting the oxidative and proteolytic potential of the incoming neutrophils. Apoptosis is a highly regulated and evolutionarily conserved programmed process of cell death that is crucial for tissue remodeling and plays a very important role in normal cell regulation and in the pathology of sepsis[65]. Studies in experimental animals and critically ill patients have demonstrated that increased apoptosis of lymphoid organs and parenchymal tissues contribute to the immune suppression, anergy, and organ dysfunction. While lymphoid cells are undergoing accelerated apoptosis, spontaneous neutrophil apoptosis associated with sepsis or SIRS is delayed[66,67]. This decreased apoptosis is thought to actually enhance tissue injury in the lung by promoting a disbalanced tissue load of neutrophils and uncontrolled 
release of toxic metabolites injurious to endothelial cells' mitochondria and collagen deposition[66,68].

We have observed an increased expression of both proand anti-apoptotic genes at $2 \mathrm{hrs}$, coinciding with maximum expression peak of cytokines and other inflammatory mediators during the first stage. Conversely, antiapoptotic and cell survival promoting genes (HIPK3, MAPK8IP1, GTSE1, and DAP), were predominant during the second stage ( $24 \mathrm{hrs)}$ where tissue regeneration-specific processes are prevalent.

\section{Extracellular matrix, tissue regeneration and functional recovery}

Within the inflammatory process, a delicate balance exists between the potential for tissue destruction and mechanisms of protective immune defense and tissue repair. Repair of wounded tissue involves a well-orchestrated sequence of events involving infiltration of macrophages that are essential for removal of necrotic cellular debris. Further events include proliferation and migration of parenchymal and connective tissue cells, extracellular matrix deposition, tissue remodeling and angiogenesis. Electron microscopy analysis of lung samples illustrates that while the neutrophil migration is dominant during the first hours post E. coli challenge, macrophage and fibroblast accumulation and collagen deposition are the foremost ultrastructural events during the second stage of the response.

ECM remodeling and synthesis is controlled by de novo synthesis and by the balance between proteolytic enzymes and their inhibitors[69]. In this study, we observed downregulation of both MMP-2 and TIMP2 and 3 at 8 hrs and $24 \mathrm{hrs}$. MMP2 cleaves several collagens and plays a role in regulation of vascularization and in the inflammatory response. The decreased expressions of MMP2, its inhibitor TIMP2 and of two collagen (type IV $\alpha 1$ and $\alpha 3$ ) components of the capillary basement membrane suggest a possible downregulation of angiogenesis in sepsis. Besides its MMP inhibition effect, TIMP3 also inhibits TNF- $\alpha$ converting enzyme (TACE), which cleave TNF- $\alpha$ and regulates its shedding[70]. TIMP3 may have a protective role in the early stage by regulating TNF-dependent systemic inflammation, as TIMP3 knocked out mice are more susceptible to LPS-induced mortality[71]. The observed decreased expression of TIMP3 during the second stage may reflect the functional recovering post $E$. coli challenge.

SERPINA3 ( $\alpha 1$-antichymotrypsin), a serpin that can inhibit potent proteases released by inflammatory cells, was strongly induced at 8 hrs post challenge. In addition to its role in matrix turnover, SERPINA3 may be also involved in the regulation of vessel's tone. SERPINA3 inhibits neutrophil cathepsin G and mast cell chymase, two proteases that convert angiotensin-1 to the active angiotensin-2, therefore SERPINA3 upregulation may be responsible for the reduced biological efficacy of the rennin-angiotensin system, and thus contribute to the cardiovascular collapse that occurs during sepsis. Our data highlight SERPINA3 as a potential therapeutic target to control the hemodynamic response of the vessel wall during sepsis. Natriuretic peptide precursor C (NPPC) is another vasoactive factor that we found to be upregulated by sepsis. NPPC possesses potent natriuretic, diuretic, and vasodilating activities and is implicated in body fluid homeostasis and blood pressure control. Normally it is expressed at low levels in endothelial cells, and its upregulation is a sign of endothelial dysfunction. The cardiovascular response to septic shock involves peripheral vasodilatation resulting in reduced systemic vascular resistance, hyporesponsiveness to vasopressors, and systemic hypotension. While natriuretic peptide precursors A and $B$ were found in increased levels in septic patients and are markers of poor outcome, currently no data on the role of NPPC in sepsis have been published.

Many differentially expressed genes in the second stage of sepsis are involved in clearing tissue debris present at the wound site, or orchestrate aspects of tissue remodeling, cell proliferation and angiogenic processes associated with the wound response. This is particularly important, as poor wound healing and recurrent infection contribute to high mortality in septic patients[72]. Our data demonstrate that genes involved in tissue repair are turned on as early as $24 \mathrm{hrs}$ after the onset of sepsis. While most of the genes are induced during the second stage (12-24 hrs), ACVR1B (activin receptor 1B), a TGF- $\beta$ receptor with protein serine/threonine kinase activity was upregulated during the first stage. Its early expression may be important for mediating TGF activity during the second stage by participating in activation of SMAD transcriptional regulators. Activin upregulation in the lung after $E$. coli challenge is also a novel finding but its role is the pathophysiology of sepsis is not clear. In vitro studies support a role in the repair of the mesenchyme and possibly also of the epithelium, thus activin receptor upregulation could be beneficial for the repair of damaged tissues. However, prolonged and/or significantly increased expression of activin may lead to involved the development of fibrosis, thus a tight control of activin level is likely to be important for normal repair[73].

The increased expression of genes such as FAP, FGF23, FLT1 and TIE1 reflects the active tissue remodeling, regeneration and functional recovery at 24 hrs. Fibroblast activation protein $\alpha$ (FAP) is a membrane-bound gelatinase involved in the control of fibroblast growth or epithelialmesenchymal interactions during tissue repair. Fibroblast 
growth factor 23(FGF23) possesses broad mitogenic and cell survival activities and is involved in cell growth and tissue repair.

TIE1 is a tyrosine kinase receptor specifically expressed in endothelial cells. Two angiopoietins, ANG1 and ANG4, activate TIE1, thus supporting a role of TIE1 in angiogenic remodeling[74]. Beside its angiopoietin-dependent function TIE1 has anti-apoptotic effects through downstream activation of PI-3 kinase and Akt pathways[75]. FLT1 (VEGFR-1) is a tyrosine kinase receptor for VEGF, VEGF B and PLGF that plays role in vascular development and regulation of vascular permeability. Recently, Yano et al reported increased circulating levels of soluble FLT1 in animal models and sepsis patients and suggested that circulating FLT1 may represent an endogenous compensatory anti-inflammatory mechanism[76]. The normal lung tissue abundantly expresses VEGF, the ligand for FLT1. VEGF is a HIF1- $\alpha$-controlled endothelial mitogen that mediates increased vascular permeability, induces angiogenesis, vasculogenesis and endothelial cell growth, promotes cell migration, and inhibits apoptosis. Like HIF- $\tilde{\alpha}$, VEGF expression was increased at $2 \mathrm{hrs}$, followed by an unexpected decrease at $24 \mathrm{hr}$. Similar decreases in VEGF mRNA and protein in lung autopsy material from septic patients were reported[77]. However, the role of VEGF in sepsis-induced lung injury is still not clear. Interestingly, plasma levels of VEGF are increased during sepsis[78] and may contribute to morbidity and mortality, but it is most likely produced by other organs (heart, liver and kidneys)[76].

In summary, in this study we explored the changes in gene expression that occur in the lung at selected time-points following E. coli infusion in baboons. To our knowledge, this is first time that the expression pattern of inflammation-associated genes and the transcriptional regulation of sepsis-related genes were investigated in a temporal manner in a baboon model. The baboon model mimics human sepsis to a large extent, therefore our model offers an important resource in the exploration of the pathways and mechanisms involved in human sepsis. We found that the primary inflammatory response genes, innate immune response genes and some anti-apoptotic genes peaked at 2 hrs. Another group of inflammatory response genes and immune response genes that function as stimulation of monocytes, natural killer and T-cell migration, and modulation of adhesion molecule expression were increased and peaked at $8 \mathrm{hrs,}$, while genes involved in wound healing and functional recovery were upregulated at $24 \mathrm{hrs}$. The transition and late expression genes may play important roles in survival. The global view of gene transcripts profile in the lungs of septic animals will significantly facilitate the understanding of the mechanism of sepsis-induced lung failure, and the pathophysiology of this disease. This may help exploring the development of new drugs and finding new targets for therapeutic intervention in severe sepsis.

\section{Methods \\ Animal experimentation}

The study protocol received prior approval by the Institutional Animal Care and Use Committee. Experiments were performed on 12 Papio cyanocephalus baboons. Nine animals were infused with live E. coli (Type B7 086a:k62; ATCC\#33985, Rockville, MD) at the sublethal dose of $10^{9}$ colony forming units (cfu)/kg and three were infused with saline (control), as described[79]. Three animals per timepoint were sacrificed at 2, 8, and 24 hrs post-infusion. Three control animals were sacrificed after saline infusion. Lung tissue was collected from similar locations, snap-frozen immediately in liquid nitrogen, and stored at $-80^{\circ} \mathrm{C}$ for mRNA and protein extraction. Adjacent lung tissue was immersed in fixative and further prepared for histology or electron microscopy.

\section{RNA isolation}

Total RNA was isolated from frozen lung tissues collected from 12 baboons (control and 3 time-point groups; three animals per group) using TRIzol reagent (Invitrogen, CA) according to manufacturer's protocol. RNA concentration was measured with a NanoDrop ${ }^{\oplus}$ ND1000 spectrophotometer (NanoDrop Technologies, Inc., Wilmington, $\mathrm{DE})$, and its integrity and purity were verified by using an Agilent 2100 Bioanalyzer Capillary Gel Electrophoresis System (Agilent, Palo Alto, CA).

\section{Microarray slide}

Microarrays were printed in-house using the Qiagen Operon v2.0 human oligonucleotide library $(21,329$ oligonucleotide probes) as previously described[80]. The 70nucleotide oligos were derived from the functionally defined genes present in the UniGene database[81] and their length and sequence specificity were optimized to reduce the cross-hybridization problems encountered with cDNA-based microarrays. The list of genes present on the array is available[82]. All 11,000 human genes of known or suspected function were represented on these arrays. In addition, most undefined open reading frames were represented (approximately 10,000 additional genes). Oligonucleotides were spotted onto Corning ${ }^{\circledast}$ UltraGAPS $^{\text {тм }}$ amino-silane-coated slides (Acton, MA, USA), rehydrated with water vapor, snap-dried at $90^{\circ} \mathrm{C}$, and then covalently fixed to the surface of the glass using 300-mJ, 254-nm wavelength UV radiation. Unbound free amines on the glass surface were blocked for 15 minutes with moderate agitation in a $143 \mathrm{mM}$ solution of succinic 
anhydride dissolved in 1-methyl-2-pyrolidinone, $20 \mathrm{mM}$ sodium borate, $\mathrm{pH}$ 8.0. Slides were rinsed for 2 minutes in distilled water, immersed for 1 minute in 95\% ethanol, and dried with a stream of nitrogen gas.

\section{Labeling and array hybridization}

cDNA was synthesized from $10 \mu \mathrm{g}$ of total RNA using CyScribe cDNA Post Labeling Kit (Amersham, Piscataway, NJ), labeled with Cy3 and purified using a Rapid PCR Purification System (Marligen Bioscience Inc, Ijamsville, MD) as previously reported[80]. Next, labeled cDNA was added to ChipHybe ${ }^{\mathrm{TM}}$ hybridization buffer (Ventana Medical Systems, Tucson, AR) containing Cot-1 DNA $(0.5 \mathrm{mg} /$ $\mathrm{ml}$ final concentration), yeast tRNA $(0.2 \mathrm{mg} / \mathrm{ml})$, and poly (dA)40-60 $(0.4 \mathrm{mg} / \mathrm{ml})$. Hybridization was performed on a Ventana Discovery system for $6 \mathrm{hr}$ at $42^{\circ} \mathrm{C}$. Microarrays were washed to a final stringency of $0.1 \times \mathrm{SSC}$, and then scanned using an Agilent DNA Microarray Scanner (Agilent Technologies, Santa Clara, CA). Fluorescent intensity was measured by Imagene ${ }^{\mathrm{TM}}$ software (BioDiscovery, Marina del Rey, CA).

\section{Array analysis}

Data normalization and robust regression was conducted to correct for technical variation among individual microarray hybridizations. This was conducted using standard statistical analysis methods in Matlab software, as described[83,84]. Genes differentially expressed between groups of samples were selected using associative analysis, as previously described[83]. For selection of genes that responded to $E$. coli challenge, each time point was compared against controls (time 0 ). The fold ratio between each time point $(2,8$, and 24 hrs) versus control (time 0 ) was generated using the average of normalized gene expression values of three biological replica of each group. The genes have a ratio either $>2$ (up-regulated) or $<0.5$ (down-regulated) were selected as candidates for further studies. Wards's hierarchical clustering was done using the Spotfire DecisionSite for Functional Genomics 8.1 package (Spotfire, Inc., Somerville, MA, USA). Similarity measure was the Euclidean distance, the clustering method was Unweighted Pair Group Method with Arithmetic Mean, and input rank was the ordering function.

\section{Real-Time RT-PCR}

Real time quantitative PCR was conducted on ABI Prism 7000 Sequence Detection System (Applied Biosystems, Foster City, CA). iTaqTM SYBR ${ }^{\circledR}$ Green Supermix (Bio-Rad, CA) was used for detection and quantitation according to manufacturer protocol. For a typical reaction, $12.5 \mu \mathrm{l}$ of iTaq SYBR Green $2 \times$ supermix, $10 \mu \mathrm{M}$ of each primer and equal or less than $200 \mathrm{ng}$ of cDNA template were mixed together and the final volume was adjusted to $25 \mu \mathrm{l}$. Expression levels of $\beta$-actin were tested along with each sample at each time point for normalization during the relative quantification. Each gene was tested using two different $\mathrm{CDNAs}$ and the analysis was run in triplicate. The default PCR conditions were as follows: (i) initiation: 2 min at $50^{\circ} \mathrm{C}$; (ii) hot start of the enzyme: 10 min at $95^{\circ} \mathrm{C}$; (iii) amplification: denaturation at $95^{\circ} \mathrm{C}$ for 15 seconds, followed by annealing and extension at $60^{\circ} \mathrm{C}$ for $1 \mathrm{~min}$; 40 cycles. The specificity of gene PCR product was evaluated by melt dissociation curve.

\section{Pathway Analysis}

Biologically relevant networks were drawn clusters of differentially expressed genes. Pathways were generated through the use of IPA software (Ingenuity Systems, Mountain View, CA). The IPA uses the Ingenuity Pathways Knowledge Base (IPKB), which is a curated database of biological networks, consisting of millions of individually-modeled peer-reviewed pathway relationships. This enabled the identification of sepsis-induced biologically relevant networks by visual inspection.

Expression data sets containing gene identifiers (Entrez Gene ID) and their corresponding expression values as fold changes were uploaded in the IPA. Each gene identifier was mapped to its corresponding gene object in the Ingenuity Pathways Knowledge Base[85]. These "focus genes" were then used as starting point for generating biological networks. The application program queries the database for interactions between focus genes and all other gene objects stored in the knowledge base, and generates a set of networks. Biological functions were assigned to each gene network by using the findings extracted from the published scientific literature and stored in the Ingenuity Pathways Knowledge Base[85] and are ranked according to the significance of that biological function to the network. The program then computes a score for each network according to the fit of the network to the set of focus genes. The score is derived from a pvalue and indicates the likelihood of the focus genes in a network being found together because of random chance. A score of greater than 2 indicates that there is a less than 1 in 100 chance that the focus genes were assembled randomly into a network due to random chance. In the current study, a score of 6 (less than 1 in 1 million chances of random grouping) or higher was used to select highly significant biological networks regulated by E. coli sepsis. Gene symbols were colored according to the temporal behavior of their expression (red indicating up- and green down-regulated expression).

\section{Multiplex ELISA for inflammatory cytokines}

Equal amounts of lung tissues were homogenized on ice with $1 \%$ Triton X-100, $60 \mathrm{mM}$ octyl-b-D glucopirannoside (OGP) in $50 \mathrm{mM}$ Tris- $\mathrm{HCl}, 150 \mathrm{mM} \mathrm{NaCl}, \mathrm{pH} 8.5$, supplemented with protease inhibitors $(1.5 \mu \mathrm{M}$ pepstatin A, $10.5 \mu \mathrm{M}$ leupeptin, $0.25 \mathrm{mM}$ pefabloc SC, $20.9 \mu \mathrm{M}$ cal- 
pain inhibitor I, $20 \mu \mathrm{M}$ calpain inhibitor II, $1.5 \mu \mathrm{M}$ aprotinin, $1 \mathrm{mM}$ benzamidine, $1 \mathrm{mM}$ EDTA, $1 \mathrm{mM}$ sodium ortho-vanadate, and $1 \mathrm{mM}$ 1,10-phenanthroline). The extracts were centrifuged at $14,500 \times \mathrm{g}$ for $15 \mathrm{~min}$, and the supernatants, representing the lung tissue lysates, were collected and stored at $-80^{\circ} \mathrm{C}$. Total protein was determined using a BCA protein kit (Pierce, Rockford, IL). Ten inflammatory cytokines (IL-1 $\beta$, IL-2, IL-4, IL-5, IL-6, IL-8, IL-10, IFN- $\gamma$, TNF- $\alpha$, and GM-CSF) were measured using a kit for human cytokines from BioSource International in conjunction with a Luminex multiplex system (Luminex Corporation)[86] and normalized to $\mathrm{mg}$ of total protein for tissue extracts or to $\mathrm{ml}$ of plasma.

\section{Morphological analysis}

For electron microscopy, tissue samples were fixed with glutaraldehyde and osmium tetraoxide, embedded in epoxy resin and further prepared and examined as previously described[87].

\section{Competing interests}

The author(s) declare that they have no competing interests.

\section{Authors' contributions}

HZ performed mRNA extraction, real time PCR validation, data processing and writing the first draft of the manuscript; YT did the bioinformatics analysis; LI performed multiplex ELISA assays; MC coordinated the microarray and bioinformatics analysis; CL coordinated the microscopy and biochemical analysis and substantially edited the manuscript, FBT contributed with the animal model of sepsis and data interpretation. FL conceived the study, participated in its designed and coordination and wrote the final version of the manuscript. All authors read and approved the final version of the manuscript.

\section{Additional material}

\section{Additional file 1}

Table_A1. The table lists the genes presented in the cluster analysis. Click here for file

[http://www.biomedcentral.com/content/supplementary/14712164-8-58-S1.doc]

\section{Additional file 2}

Table_A2. The table lists the genes of the IPA networks at the time point 2 hrs.

Click here for file

[http://www.biomedcentral.com/content/supplementary/14712164-8-58-S2.doc]

\section{Additional file 3}

Table_A3. The table lists the genes of the IPA networks at the time point 8 hrs.

Click here for file

[http://www.biomedcentral.com/content/supplementary/1471-

2164-8-58-S3.doc]

\section{Additional file 4}

Table_A4. The table lists the genes of the IPA networks at the time point 24 hrs.

Click here for file

[http://www.biomedcentral.com/content/supplementary/1471-

2164-8-58-S4.doc]

\section{Acknowledgements}

This work was supported by the NIH grant 5ROIGM037704-17 (FL and FBT).

We thank Todd Ham for technical support with the electron microscopy, Glenn Peer and Scott Freeman for technical support with animal experimentation and Drs. Charles T. Esmon and Ricardo Saban for critical reading of the manuscript.

\section{References}

I. Hotchkiss RS, Karl IE: The pathophysiology and treatment of sepsis. N Engl J Med 2003, 348(2): I38-I 50 .

2. Chinnaiyan AM, Huber-Lang M, Kumar-Sinha C, Barrette TR, Shankar-Sinha S, Sarma VJ, Padgaonkar VA, Ward PA: Molecular signatures of sepsis: multiorgan gene expression profiles of systemic inflammation. Am J Pathol 200I, I 59(4): I 199-1209.

3. Zhang G, Ghosh S: Toll-like receptor-mediated NF-kappaB activation: a phylogenetically conserved paradigm in innate immunity. J Clin Invest 200I, I07(I): I3-19.

4. Benjamim CF, Hogaboam CM, Kunkel SL: The chronic consequences of severe sepsis. J Leukoc Biol 2004, 75(3):408-4I 2.

5. Skidgel RA, Gao XP, Brovkovych V, Rahman A, Jho D, Predescu S, Standiford TJ, Malik AB: Nitric oxide stimulates macrophage inflammatory protein-2 expression in sepsis. J Immunol 2002, 169(4):2093-2101.

6. Jeyaseelan S, Chu HW, Young SK, Worthen GS: Transcriptional profiling of lipopolysaccharide-induced acute lung injury. Infect Immun 2004, 72(I 2):7247-7256.

7. Kitamura $Y$, Hashimoto S, Mizuta N, Kobayashi A, Kooguchi K, Fujiwara I, Nakajima H: Fas/FasL-dependent apoptosis of alveolar cells after lipopolysaccharide-induced lung injury in mice. Am J Respir Crit Care Med 200I, I63(3 Pt I):762-769.

8. Ebong SJ, Call DR, Bolgos G, Newcomb DE, Granger Jl, O'Reilly M, Remick DG: Immunopathologic responses to non-lethal sepsis. Shock 1999, I2(2): II8-126.

9. Takakuwa T, Endo S, Inada K, Kasai T, Yamada Y, Ogawa M: Assessment of inflammatory cytokines, nitrate/nitrite, type II phospholipase A2, and soluble adhesion molecules in systemic inflammatory response syndrome. Res Commun Mol Pathol Pharmacol 1997, 98(I):43-52.

10. Zhao B, Bowden RA, Stavchansky SA, Bowman PD: Human endothelial cell response to gram-negative lipopolysaccharide assessed with cDNA microarrays. Am J Physiol Cell Physiol 200I, 28 I(5): CI587-I595.

II. Franscini N, Bachli EB, Blau N, Leikauf MS, Schaffner A, Schoedon G: Gene expression profiling of inflamed human endothelial cells and influence of activated protein C. Circulation 2004, I l 0( I 8):2903-2909.

12. McCormick SM, Eskin SG, McIntire LV, Teng CL, Lu CM, Russell CG, Chittur KK: DNA microarray reveals changes in gene expression of shear stressed human umbilical vein endothelial cells. Proc Natl Acad Sci USA 200I, 98(16):8955-8960.

13. Albrecht EA, Chinnaiyan AM, Varambally S, Kumar-Sinha C, Barrette TR, Sarma JV, Ward PA: C5a-induced gene expression in human umbilical vein endothelial cells. Am 」 Pathol 2004, 164(3):849-859.

14. Tsukahara $Y$, Lian Z, Zhang $X$, Whitney $C$, Kluger $Y$, Tuck D, Yamaga S, Nakayama Y, Weissman SM, Newburger PE: Gene expression in human neutrophils during activation and priming by bacterial lipopolysaccharide. J Cell Biochem 2003, 89(4):848-86I.

15. Calvano SE, Xiao W, Richards DR, Felciano RM, Baker HV, Cho RJ, Chen RO, Brownstein BH, Cobb JP, Tschoeke SK, et al: A networkbased analysis of systemic inflammation in humans. Nature 2005, 437(706I): I032-1037. 
16. Cobb JP, Laramie JM, Stormo GD, Morrissey IJ, Shannon WD, Qiu Y Karl IE, Buchman TG, Hotchkiss RS: Sepsis gene expression profiling: murine splenic compared with hepatic responses determined by using complementary DNA microarrays. Crit Care Med 2002, 30( I 2):27| |-272 I.

17. Taylor FB Jr: Staging of the pathophysiologic responses of the primate microvasculature to Escherichia coli and endotoxin: examination of the elements of the compensated response and their links to the corresponding uncompensated lethal variants. Crit Care Med 200I, 29(7 Suppl):S78-89.

18. Caceres M, Lachuer J, Zapala MA, Redmond JC, Kudo L, Geschwind $\mathrm{DH}$, Lockhart DJ, Preuss TM, Barlow C: Elevated gene expression levels distinguish human from non-human primate brains. Proc Natl Acad Sci USA 2003, I 00(22): I 3030-I3035.

19. Khaitovich P, Muetzel B, She X, Lachmann M, Hellmann I, Dietzsch J, Steigele S, Do HH, Weiss G, Enard W, et al:: Regional patterns of gene expression in human and chimpanzee brains. Genome research 2004, |4(8): |462-|473.

20. Karaman MW, Houck ML, Chemnick LG, Nagpal S, Chawannakul D, Sudano D, Pike BL, Ho VV, Ryder OA, Hacia JG: Comparative analysis of gene-expression patterns in human and African great ape cultured fibroblasts. Genome research 2003, I3(7): $1619-1630$

21. Aavik E, Mahapatra A, Boldrick J, Chen X, Barry C, Dutoit D, Sarwa $M$, Hayry P: Correlation between gene expression and mor phological alterations in baboon carotid after balloon dilatation injury. Faseb J 2005, I9(I): I30-132.

22. Spindel ER, Pauley MA, Jia Y, Gravett C, Thompson SL, Boyle NF, Ojeda SR, Norgren RB Jr: Leveraging human genomic information to identify nonhuman primate sequences for expression array development. BMC genomics 2005, 6:160.

23. Chismar JD, Mondala T, Fox HS, Roberts E, Langford D, Masliah E Salomon DR, Head SR: Analysis of result variability fromhighdensity oligonucleotide arrays comparing same-species and cross-species hybridizations. Biotechniques 2002, 33(3):5 I6-5 I8. 520, 522 passim

24. Wang Z, Lewis MG, Nau ME, Arnold A, Vahey MT: Identification and utilization of inter-species conserved (ISC) probesets on Affymetrix human GeneChip platforms for the optimization of the assessment of expression patterns in non human primate (NHP) samples. BMC bioinformatics 2004, 5: 165.

25. Hiromatsu T, Yajima T, Matsuguchi T, Nishimura $H$, Wajiwalku W Arai T, Nimura Y, Yoshikai Y: Overexpression of interleukin- I 5 protects against Escherichia coli-induced shock accompanied by inhibition of tumor necrosis factor-alpha-induced apoptosis. J Infect Dis 2003, I87(9): |442-|45|.

26. Letunic I, Copley RR, Schmidt S, Ciccarelli FD, Doerks T, Schultz J, Ponting CP, Bork P: SMART 4.0: towards genomic data integration. Nucleic Acids Res 2004:D I 42-I44

27. SMART: Main Page [http://smart.embl-heidelberg.de]

28. Huang CY, Wu YM, Hsu CY, Lee WS, Lai MD, Lu T], Huang CL, Leu TH, Shih HM, Fang HI, et al:: Caspase activation of mammalian sterile 20-like kinase 3 (Mst3). Nuclear translocation and induction of apoptosis. J Biol Chem 2002, 277(37):34367-34374.

29. Riedemann NC, Guo RF, Ward PA: The enigma of sepsis. J Clin Invest 2003, I I 2(4):460-467.

30. Taylor FB Jr, Wada H, Kinasewitz G: Description of compensated and uncompensated disseminated intravascular coagulation (DIC) responses (non-overt and overt DIC) in baboon models of intravenous and intraperitoneal Escherichia coli sepsis and in the human model of endotoxemia: toward a better definition of DIC. Crit Care Med 2000, 28(9 Suppl):SI2-19.

31. Gomes I, Sharma TT, Mahmud N, Kapp JD, Edassery S, Fulton N, Liang J, Hoffman R, Westbrook CA: Highly abundant genes in the transcriptosome of human and baboon CD34 antigen-positive bone marrow cells. Blood 200I, 98(I):93-99.

32. Cariello NF, Romach EH, Colton HM, Ni H, Yoon L, Falls JG, Casey W, Creech D, Anderson SP, Benavides GR, et al: Gene expression profiling of the PPAR-alpha agonist ciprofibrate in the cynomolgus monkey liver. Toxicol Sci 2005, 88(I):250-264.

33. Liu SF, Malik AB: NF-kappa $B$ activation as a pathological mechanism of septic shock and inflammation. Am J Physiol Lung Cell Mol Physiol 2006, 290(4):L622-L645.

34. Bhatia M, Moochhala S: Role of inflammatory mediators in the pathophysiology of acute respiratory distress syndrome. J Pathol 2004, 202(2): |45-I56.
35. Ward PA: Acute lung injury: how the lung inflammatory response works. Eur Respir J Suppl 2003, 44:22s-23s.

36. Miller EJ, Cohen AB, Matthay MA: Increased interleukin-8 concentrations in the pulmonary edema fluid of patients with acute respiratory distress syndrome from sepsis. Crit Care Med 1996, 24(9): | 448-|454.

37. Tsujimoto H, Ono S, Majima T, Kawarabayashi N, Takayama E, Kinoshita M, Seki S, Hiraide H, Moldawer LL, Mochizuki H: Neutrophil elastase, MIP-2, and TLR-4 expression during human and experimental sepsis. Shock 2005, 23(I):39-44.

38. Jansen PM, van der Pouw Kraan TC, de Jong IW, van Mierlo G, Wijdenes J, Chang AA, Aarden LA, Taylor FB Jr, Hack CE: Release of interleukin-I2 in experimental Escherichia coli septic shock in baboons: relation to plasma levels of interleukin- 10 and interferon-gamma. Blood |996, 87(I2):5 |44-5I5I.

39. Ryckman C, Vandal K, Rouleau P, Talbot M, Tessier PA: Proinflammatory activities of SI00: proteins SIO0A8, SIO0A9, and SI00A8/A9 induce neutrophil chemotaxis and adhesion. Immunol 2003, I 70(6):3233-3242.

40. Vandal K, Rouleau P, Boivin A, Ryckman C, Talbot M, Tessier PA: Blockade of SIOOA8 and SIO0A9 suppresses neutrophil migration in response to lipopolysaccharide. J Immunol 2003, | 7 | (5):2602-2609.

4I. Foell D, Wittkowski H, Vogl T, Roth J: SI 00 proteins expressed in phagocytes: a novel group of damage-associated molecular pattern molecules. J Leukoc Biol 2006.

42. Hsu K, Passey RJ, Endoh Y, Rahimi F, Youssef P, Yen T, Geczy CL: Regulation of SIO0A8 by glucocorticoids. J Immunol 2005 , I 74(4):2318-2326.

43. Hermani A, De Servi B, Medunjanin S, Tessier PA, Mayer D: SI 00A8 and SI00A9 activate MAP kinase and NF-kappaB signaling pathways and trigger translocation of RAGE in human prostate cancer cells. Exp Cell Res 2006, 3 I 2(2): I84- I97.

44. Frosch M, Strey A, Vogl T, Wulffraat NM, Kuis W, Sunderkotter C, Harms E, Sorg C, Roth J: Myeloid-related proteins 8 and I4 are specifically secreted during interaction of phagocytes and activated endothelium and are useful markers for monitoring disease activity in pauciarticular-onset juvenile rheumatoid arthritis. Arthritis Rheum 2000, 43(3):628-637.

45. Frosch M, Vogl T, Seeliger S, Wulffraat N, Kuis W, Viemann D, Foell $D$, Sorg C, Sunderkotter C, Roth J: Expression of myeloid-related proteins 8 and 14 in systemic-onset juvenile rheumatoid arthritis. Arthritis Rheum 2003, 48(9):2622-2626

46. Vos JB, van Sterkenburg MA, Rabe KF, Schalkwijk J, Hiemstra PS, Datson NA: Transcriptional response of bronchial epithelial cells to Pseudomonas aeruginosa: identification of early mediators of host defense. Physiol Genomics 2005, 2 I (3):324-336.

47. Pechkovsky DV, Zalutskaya OM, Ivanov GI, Misuno NI: Calprotectin (MRP8/I4 protein complex) release during mycobacterial infection in vitro and in vivo. FEMS Immunol Med Microbiol 2000 , 29(I):27-33.

48. Guenzi E, Topolt K, Cornali E, Lubeseder-Martellato C, Jorg A, Matzen K, Zietz C, Kremmer E, Nappi F, Schwemmle M, et al:: The helical domain of GBP-I mediates the inhibition of endothelial cell proliferation by inflammatory cytokines. Embo J 200I, 20(20):5568-5577.

49. Lubeseder-Martellato C, Guenzi E, Jorg A, Topolt K, Naschberger E, Kremmer E, Zietz C, Tschachler E, Hutzler P, Schwemmle M, et al.: Guanylate-binding protein-I expression is selectively induced by inflammatory cytokines and is an activation marker of endothelial cells during inflammatory diseases. Am J Pathol 2002, I 6 I(5): I 749-1759.

50. Vestal DJ, Buss JE, McKercher SR, Jenkins NA, Copeland NG, Kelner GS, Asundi VK, Maki RA: Murine GBP-2: a new IFN-gammainduced member of the GBP family of GTPases isolated from macrophages. J Interferon Cytokine Res 1998, I 8( I I ):977-985

5I. Gorbacheva VY, Lindner D, Sen GC, Vestal DJ: The interferon (IFN)-induced GTPase, mGBP-2. Role in IFN-gammainduced murine fibroblast proliferation. I Biol Chem 2002, 277(8):6080-6087.

52. Bone RC, Grodzin CJ, Balk RA: Sepsis: a new hypothesis for pathogenesis of the disease process. Chest 1997, I | 2( I):235-243.

53. Neumann B, Zantl N, Veihelmann A, Emmanuilidis K, Pfeffer K, Heidecke $C D$, Holzmann $B$ : Mechanisms of acute inflammatory 
lung injury induced by abdominal sepsis. Int Immunol 1999 , I I(2):217-227.

54. Goodman RB, Strieter RM, Martin DP, Steinberg KP, Milberg JA, Maunder RJ, Kunkel SL, Walz A, Hudson LD, Martin TR: Inflammatory cytokines in patients with persistence of the acute respiratory distress syndrome. Am J Respir Crit Care Med 1996, I54(3 Pt I):602-6II.

55. Reddy RC, Chen GH, Tekchandani PK, Standiford TJ: Sepsisinduced immunosuppression: from bad to worse. Immunol Res 200I, 24(3):273-287.

56. Pachot A, Monneret G, Brion A, Venet F, Bohe J, Bienvenu J, Mougin B, Lepape A: Messenger RNA expression of major histocompatibility complex class II genes in whole blood from septic shock patients. Crit Care Med 2005, 33(I):31-38. discussion 236237

57. Redl H, Schlag G, Schiesser A, Davies J: Thrombomodulin release in baboon sepsis: its dependence on the dose of Escherichia coli and the presence of tumor necrosis factor. I Infect Dis 1995, $171(6)$ : I522-1527.

58. Gutteridge JM, Mitchell J: Redox imbalance in the critically ill. $\mathrm{Br}$ Med Bull 1999, 55(I):49-75.

59. Gutteridge JM: Lipid peroxidation and antioxidants as biomarkers of tissue damage. Clin Chem 1995, 4I(12 Pt 2):1819-1828.

60 . Ince $C$, Sinaasappel M: Microcirculatory oxygenation and shunting in sepsis and shock. Crit Care Med 1999, 27(7):1369-1377.

61. Nakamura $\mathrm{H}$, Matsuda M, Furuke K, Kitaoka $Y$, Iwata S, Toda K, Inamoto T, Yamaoka Y, Ozawa K, Yodoi J: Adult T cell leukemiaderived factor/human thioredoxin protects endothelial F-2 cell injury caused by activated neutrophils or hydrogen peroxide. Immunol Lett 1994, 42(I-2):75-80.

62. Nakamura H, Nakamura K, Yodoi J: Redox regulation of cellular activation. Annu Rev Immunol 1997, I 5:35 I-369.

63. Djavaheri-Mergny M, Javelaud D, Wietzerbin J, Besancon F: NF-kappaB activation prevents apoptotic oxidative stress via an increase of both thioredoxin and MnSOD levels in TNFalpha-treated Ewing sarcoma cells. FEBS Lett 2004, 578(I2): III-II5.

64. Zhao Y, Kiningham KK, Lin SM, St Clair DK: Overexpression of MnSOD protects murine fibrosarcoma cells (FSa-II) from apoptosis and promotes a differentiation program upon treatment with 5-azacytidine: involvement of MAPK and NFkappaB pathways. Antioxid Redox Signal 200I, 3(3):375-386.

65. Hotchkiss RS, Tinsley KW, Swanson PE, Karl IE: Endothelial cell apoptosis in sepsis. Crit Care Med 2002, 30(5 Suppl):S225-228.

66. Jimenez MF, Watson RW, Parodo J, Evans D, Foster D, Steinberg M, Rotstein OD, Marshall JC: Dysregulated expression of neutrophil apoptosis in the systemic inflammatory response syndrome. Arch Surg 1997, I32(I 2): I 263-1269. discussion I269-1270

67. Keel M, Ungethum U, Steckholzer U, Niederer E, Hartung T, Trentz $O$, Ertel W: Interleukin- 10 counterregulates proinflammatory cytokine-induced inhibition of neutrophil apoptosis during severe sepsis. Blood 1997, 90(9):3356-3363.

68. Matute-Bello G, Liles WC, Radella F 2nd, Steinberg KP, Ruzinski JT, Jonas M, Chi EY, Hudson LD, Martin TR: Neutrophil apoptosis in the acute respiratory distress syndrome. Am J Respir Crit Care Med 1997, I 56(6): 1969-1977.

69. Eickelberg O, Kohler E, Reichenberger F, Bertschin S, Woodtli T, Erne P, Perruchoud AP, Roth M: Extracellular matrix deposition by primary human lung fibroblasts in response to TGF-beta I and TGF-beta3. Am J Physiol 1999, 276(5 Pt I):L8I4-824.

70. Lee MH, Rapti M, Murphy G: Total conversion of tissue inhibitor of metalloproteinase (TIMP) for specific metalloproteinase targeting: fine-tuning TIMP-4 for optimal inhibition of tumor necrosis factor-\{alpha\}-converting enzyme. J Biol Chem 2005, 280(16): 15967-15975.

7I. Smookler DS, Mohammed FF, Kassiri Z, Duncan GS, Mak TW, Khokha R: Tissue inhibitor of metalloproteinase 3 regulates TNF-dependent systemic inflammation. J Immunol 2006, I 76(2):72|-725.

72. Ayala A, Chung CS, Grutkoski PS, Song GY: Mechanisms of immune resolution. Crit Care Med 2003, 3 I (8 Suppl):S558-57I.

73. Munz B, Hubner G, Tretter Y, Alzheimer C, Werner S: A novel role of activin in inflammation and repair. J Endocrinol 1999, 161(2):187-193.

74. Saharinen P, Kerkela K, Ekman N, Marron M, Brindle N, Lee GM, Augustin $\mathrm{H}$, Koh GY, Alitalo K: Multiple angiopoietin recom- binant proteins activate the Tiel receptor tyrosine kinase and promote its interaction with Tie2. J Cell Biol 2005, I69(2):239-243.

75. Eklund L, Olsen BR: Tie receptors and their angiopoietin ligands are context-dependent regulators of vascular remodeling. Exp Cell Res 2006, 3 I 2(5):630-64I.

76. Yano K, Liaw PC, Mullington JM, Shih SC, Okada H, Bodyak N, Kang PM, Toltl L, Belikoff B, Buras J, et al.: Vascular endothelial growth factor is an important determinant of sepsis morbidity and mortality. The Journal of experimental medicine 2006 , 203(6): I $447-1458$.

77. Tsokos M, Pufe T, Paulsen F, Anders S, Mentlein R: Pulmonary expression of vascular endothelial growth factor in sepsis. Arch Pathol Lab Med 2003, I 27(3):33 I-335.

78. Pickkers P, Sprong T, Eijk L, Hoeven H, Smits P, Deuren M: Vascular endothelial growth factor is increased during the first 48 hours of human septic shock and correlates with vascular permeability. Shock 2005, 24(6):508-5I2

79. Taylor FB Jr, Stearns-Kurosawa DJ, Kurosawa S, Ferrell G, Chang AC, Laszik Z, Kosanke S, Peer G, Esmon CT: The endothelial cell protein $\mathrm{C}$ receptor aids in host defense against Escherichia coli sepsis. Blood 2000, 95(5): 1680-1686.

80. Szodoray P, Alex P, Frank MB, Turner M, Turner S, Knowlton N, Cadwell C, Dozmorov I, Tang Y, Wilson PC, et al: A genome-scale assessment of peripheral blood B-cell molecular homeostasis in patients with rheumatoid arthritis. Rheumatology (Oxford) 2006.

81. UniGene [http://www.ncbi.nlm.nih.gov/UniGene]

82. OMRF Microarray Research Facility [http://microar ray.omrf.org/frank/microarray.html]

83. Dozmorov I, Centola M: An associative analysis of gene expression array data. Bioinformatics (Oxford, England) 2003, 19(2):204-2II.

84. Knowlton N, Dozmorov IM, Centola M: Microarray Data Analysis Toolbox (MDAT): for normalization, adjustment and analysis of gene expression data. Bioinformatics (Oxford, England) 2004, 20(18):3687-3690.

85. Ingenuity Pathways Knowledge Base [http://www.ingenu ity.com/products/PathwaysKnowledge.pdf]

86. Carlos CA, Dong HF, Howard OM, Oppenheim JJ, Hanisch FG, Finn OJ: Human tumor antigen MUCI is chemotactic for immature dendritic cells and elicits maturation but does not promote Th I type immunity. J Immunol 2005, I75(3):1628-I635.

87. Lupu C, Westmuckett AD, Peer G, Ivanciu L, Zhu H, Taylor FB Jr, Lupu F: Tissue factor-dependent coagulation is preferentially up-regulated within arterial branching areas in a baboon model of Escherichia coli sepsis. Am J Pathol 2005, 167(4): $1|6|-\mid 172$.

Publish with Biomed Central and every scientist can read your work free of charge

"BioMed Central will be the most significant development for disseminating the results of biomedical research in our lifetime. "

Sir Paul Nurse, Cancer Research UK

Your research papers will be:

- available free of charge to the entire biomedical community

- peer reviewed and published immediately upon acceptance

- cited in PubMed and archived on PubMed Central

- yours - you keep the copyright

Submit your manuscript here:

http://www.biomedcentral.com/info/publishing_adv.asp
BioMedcentral 